\title{
Referring Discovery Tasks to Special Masters: Is Rule 53 a Source of Authority and Restrictions?
}

\author{
Wayne D. Brazil
}

The author concludes that federal judges who want to appoint special masters to perform duties related to civil discovery may not look to the Federal Rules of Civil Procedure for authority to do so. By examining the historical backdrop against which the original rules were written, as well as the minutes of the proceedings of the first Advisory Committee, Brazil demonstrates that neither Rule 53 nor any other rule was designed to grant federal trial courts power to assign pretrial discovery tasks to special masters. In fact, the evidence the author marshalls shows that the original Advisory Committee explicitly rejected the idea that the Federal Rules should authorize even a limited role for special masters in connection with discovery depositions.

Finding no authority for such appointments in the Federal Rules, the author turns to the judiciary's 'inherent power." Drawing principles from the seminal Supreme Court opinion in this area, Brazil infers that in some circumstances the courts' inherent authority is a sufficient premise for delegating discovery tasks to special masters. Noting that the reported cases contain no clear guidelines about when or how federal judges should use this authority in making pretrial appointments, Brazil concludes by calling for a new federal rule covering this important subject.

\section{INTRODUCTION}

During the last three decades federal courts have appointed special masters $^{1}$ to perform a wide range of quasi-judicial services during the discovery

Wayne D. Brazl is Professor of the Law, Hastings College of the Law, University of California, San Francisco; Affiliated Scholar, American Bar Foundation. B.A., 1966, Stanford University; M.A., 1967, Ph.D., 1975, Harvard University; J.D., 1975, University of California, Berkeley.

The author would like to express his appreciation to the American Bar Foundation for supporting the research reflected in this article. He also would like to thank Louis Tuchman (Yale Law School, Class of 1984) and Marsie H. Lasman and William T. McCullough (Hastings College of the Law, Classes of 1983 and 1984, respectively) for their valuable work as research assistants.

1. As used in this article, the phrase "special master" refers to a private attorney, retired judge, or a law professor, who is appointed on an ad hoc (case-by-case) basis to help a trial court perform judicial tasks associated with civil litigation. As I use the phrase, a special master does not include a United States magistrate, who may be used to perform similar services on behalf of the trial court. Magistrates are public employees and their powers are statutorily prescribed (see 28 U.S.C. § 636 (1976 \& Supp. V 1981)). There is excellent recent scholarly discussion of the roles magistrates can play in civil actions and of the 
stage of civil actions. ${ }^{2}$ Many federal judges have assumed that they can order such references without the consent of the parties under the authority of Rule 53 of the Federal Rules of Civil Procedure. They also have assumed that such references are permissible only if the preconditions of paragraph (b) of Rule 53 are satisfied. I have concluded that these assumptions are misplaced. As I explain in the pages that follow Rule 53 was designed to authorize and to limit only the kinds of trial-stage references that were wellestablished features of federal equity practice before 1938. Thus, if the Supreme Court construes Rule 53 as its drafters intended, ${ }^{3}$ federal judges will have to look elsewhere for authority to delegate discovery tasks to masters. As important, federal courts should not assume that the body of doctrine interpreting key provisions of Rule 53 applies without qualification to pretrial references. This does not mean, however, that federal judges can appoint special masters in the discovery stage only if all the parties consent.

Supreme Court precedents support the conclusion that a federal trial court has inherent authority to assign nondispositive pretrial functions to masters even over the objection of one or more of the litigants. The cases that support this conclusion make it clear that there are limits on the scope of inherent power in this context. Unfortunately, none of the reported opinions identifies those limits with precision. Nor do the published opinions offer federal judges who seek to exercise this authority a clear set of guidelines about how to do so. Since Rule 53 was not designed to cover references of discovery matters, it also fails to provide directives for such references. As the explication of authority problems in the pages that follow shows, there is a real need for the Advisory Committee to draft a new rule that would offer.direct guidance about when and how special masters should be used during the discovery stage of civil actions. ${ }^{4}$

\section{Does Rule 53 Authorize AND Limit References of Discovery Matters to Special Masters?}

Only one of the Federal Rules of Civil Procedure purports to confer on federal judges the power to appoint special masters. Rule 53 clearly contemplates appointments of masters to assist courts in making findings of fact at the trial stage of complex cases. ${ }^{5}$ Was Rule 53 also intended to authorize

special considerations that affect the scope of their authority. See, e.g., Peter G. McCabe, The Federal Magistrate Act of 1979, 16 Harv. J. Legis. 343 (1979); Linda J. Silberman, Masters and Magistrates Part I: The English Model, 50 N.Y.U. L. Rev. 1070 (1975); and id., Masters and Magistrates Part II: The American Analogue, 50 N.Y.U. L. Rev. 1297 (1975). See also Comment, Masters and Magistrates in the Federal Courts, 88 Harv. L. Rev. 779 (1975).

2. For a description of many of these tasks and citations to cases in which they have been performed, see Wayne D. Brazil, Special Masters in the Pretrial Development of Big Cases: Potential and Problems, 1982 A.B.F. Res. J. 287, 295-302.

3. I discuss the significance the Court may ascribe to the Advisory Committee's views at pp. 147-48 infra.

4. I have suggested one possible version of such a new rule in Wayne D. Brazil, Geoffrey C. Hazard, Jr., \& Paul R. Rice, Managing Complex Litigation: A Practical Guide to the Use of Special Masters 384-88 (Chicago: American Bar Foundation, 1983).

5. See, e.g., Troyak v. Enos, 204 F.2d 536, 544-55 (7th Cir. 1953); cf. Ruiz v. Estelle, 679 F.2d 1115, 1159-63 (5th Cir. 1982). 
federal judges to appoint special masters to help perform judicial tasks during the pretrial discovery stage of civil lawsuits?

To some people this may seem a silly (i.e., a self-answering) question. Many federal courts have assumed that Rule 53 is a source of authority for pretrial references. ${ }^{6}$ Some courts even have assumed that Rule 53 is a federal judge's only source of authority to appoint a master and, therefore, that the rule's requirements must be satisfied and its procedures followed every time a reference is made, regardless of its purpose. ${ }^{7}$ If these assumptions are well made, the requirements imposed by paragraph (b) of Rule 53 might present serious obstacles to creative use of masters to help expedite preparation for trial (or settlement) in civil actions. Paragraph (b) imposes the following preconditions on references made under Rule 53:

(b) Reference. A reference to a master shall be the exception and not the rule. In actions to be tried by a jury, a reference shall be made only when the issues are complicated; in actions to be tried without a jury, save in matters of account and of difficult computation of damages, a reference shall be made only upon a showing that some exceptional condition requires it. ${ }^{8}$

The Supreme Court has construed the "exceptional condition" requirement in Rule 53(b) as erecting a formidable barrier to trial-stage references. When a judge refers initial responsibility for an entire trial to a master, this barrier cannot be overcome even by a showing that the issues the case presents are complex, that trying the matter would consume substantial judicial resources, and that the court's calendar is extremely congested..$^{9}$ While it is not clear that the Supreme Court would hold that the exceptional condition requirement is as difficult to satisfy for pretrial references as for trial-stage appointments, ${ }^{10}$ it is clear that district judges who wanted to delegate pretrial tasks would have substantially less freedom to do so if they were constrained by Rule 53(b).

But questions about what the exceptional condition requirement might mean in the context of pretrial references are only important if Rule 53 applies to such references. If Rule 53 is not a source of authority for references

6. The following are some of the cases in which courts appear to have assumed that Rule 53 authorizes and guides pretrial discovery references: In re Ampicillin Antitrust Litig., 81 F.R.D. 377 (D.D.C. 1978); United States v. International Business Mach. Co., 76 F.R.D. 97 (S.D.N.Y. 1977); Omnium Lyonnais D'Etancheite et Revetement Asphalte v. Dow Chem. Co., 73 F.R.D. 114 (C.D. Cal. 1977); Stentor Elec. Mfg. Co. v. Klaxon Co., 28 F. Supp. 665 (D. Del. 1939); Fisher v. Harris, Upham \& Co., 61 F.R.D. 447 (S.D.N.Y. 1973); Tivoli Realty v. Paramount Pictures, 10 F.R.D. 201 (D. Del. 1950); Waldo Theatre Corp. v. Dondis, 1 F.R.D. 591 (D. Me. 1941); Denton v. Mr. Swiss, 564 F.2d 236 (8th Cir. 1977); United States v. AT\&T, 461 F. Supp. 1314, 1320 n.15 (D.D.C. 1978).

7. See Arthur Murray, Inc. v. Oliver, 364 F.2d 28 (8th Cir. 1966), cf. Wilver v. Fisher, 387 F.2d 66 (10th Cir. 1967).

8. Fed. R. Civ. P. 53(b).

9. La Buy v. Howes Leather Co., 352 U.S. 249, 253, 259 (1957).

10. Some commentators have suggested that the courts might require less "exceptional" conditions for pretrial references or that this precondition simply does not apply to references when courts delegate nondispositive tasks to masters in advance of trial. See Irving R. Kaufman, Masters in the Federal Courts: Rule 53, 58 Colum. L. Rev. 452, 462, 465 (1958); Silberman, Part II, supra note 1, at 1432-33 \& n.264; Comment, supra note 1, at 798 n.130; Comment, Developments in the Law-Discovery, 74 Harv. L. Rev. 940, 1004 (1961). 
prior to the fact-finding stage, judges who want to make pretrial appointments need not struggle to understand its constraints.

I should emphasize that the Supreme Court has never addressed the issue we explore here. The Court has not even intimated how it might respond if pressed to decide whether Rule 53 authorizes and restricts references of pretrial discovery matters. ${ }^{11}$ I also should acknowledge an important fact of jurisprudential life. Rule 53 will mean whatever the Supreme Court says it means. ${ }^{12}$ If the Court believes that the most sensible way to proceed in this area is to hold that this rule applies to discovery-stage references, the Court could so construe the rule. There is no language in the rule that stands as an insurmountable barrier to such an interpretation. For two reasons, however, I suspect that the Court is not likely to follow this course. One is that explaining away the historical evidence I describe in the pages that follow would prove a difficult and perhaps embarrassing task. But a second consideration should weigh even heavier. Because Rule 53 was written in contemplation only of conventional trial-stage references, it offers very little guidance to judges who are interested in referring discovery tasks. Thus, rather than stretch Rule 53 to cover situations its drafters did not foresee, it would make better sense to face the fact that Rule 53 does not do the job for pretrial references and to draft a new rule that will meet the district courts' needs in this area.

A few comments are in order, at the outset, about how I attempt to measure the reach of Rule 53. I began by looking for evidence from the cases. Unfortunately, this effort yielded very little: there is no reported opinion in which a court has examined the history or structure of Rule 53 to determine whether it was intended to apply to references of discovery matters. The few judicial pronouncements on this subject reflect little more than untested and

11. I assume that it is not safe to search for any such intimations in the Court's denials of petitions for certiorari. It may be noteworthy, however, that shortly after its opinion in $L a B u y$ was published, the Court refused to review an opinion in which the Court of Appeals for the Eighth Circuit approved reference of discovery matters to a special master and insisted that, independent of Rule 53, federal judges have inherent authority to make such appointments when deemed "essential" for "the administration of justice." See First Iowa Hydro Elec. Coop. v. Iowa-Illinois Gas \& Elec. Co., 245 F.2d 613, 627 (8th Cir.), cert. denied, 355 U.S. 871 (1957).

12. Former attorney general William D. Mitchell, chairman of the original Advisory Committee, put the matter nicely while speaking at an institute in 1938 that was designed to explain the new rules. Mitchell warned his audience that:

\footnotetext{
What is said here at this meeting by members of the Advisory Committee must be taken with a grain of salt, for two reasons. The first is that officially nobody but the justices of the Supreme Court know what these rules mean. We have no right to speak for them, and what they say about the rules ultimately will control.

Furthermore, I think it was Lord Bacon who said that a person who drafted a document was least qualified to interpret it, because he always had in mind what he intended to say rather than what he actually said.
}

See American Bar Association, Rules of Civil Procedure for the District Courts of the United States, with Notes, and Proceedings of the Institute on Federal Rules, Cleveland, Ohio, July 21-23, 1938, ed. by William W. Dawson, at 179 (1938).

I assume that Congress would not care enough about how the Court interprets Rule 53 to try to legislatively impose some alternative view.

For a general description and critique of the process by which Federal Rules of Civil Procedure are generated today see Winifred R. Brown, Federal Rulemaking: Problems and Possibilities (Washington, D.C.: Federal Judicial Center, 1981). 
unexplained assumptions. ${ }^{13}$ Faced with this dearth of judicial authority, I have conducted my own examination of the historical evidence and of the structure of the rule. The focus of my historical research is on the intentions of the Advisory Committee that drafted the original version of Rule 53 (no changes of significance for our purposes have been made in the rule). My effort to ascertain the expectations of the drafters of the rule has two components. One consists of an exploration of the system of referencing in federal courts that existed prior to 1938. I undertake that task because it seems clear that the original Advisory Committee intended Rule 53 to preserve, with only modest changes, the referencing practices that federal courts had developed under the Equity Rules (as revised in 1912). ${ }^{14}$ The second component of the historical inquiry revolves around an analysis of the records of the Advisory Committee's proceedings between 1935 and 1937. The transcripts of those proceedings, supplemented by comments from published sources, leave little doubt about what the Committee expected Rule 53 to do.

This is an appropriate juncture to address a basic question: what role in assessing the meaning of a rule will the Supreme Court ascribe to the intentions of the Advisory Committee that wrote the rule? For reasons about which we can only speculate, ${ }^{15}$ in 1938 Chief Justice Hughes placed the official records of the Advisory Committee under a seal that subsequent Chief Justices have preserved. ${ }^{16}$ At the same time the Court informed members of the original Advisory Committee that it would be "undesirable" for them "to write books on the subject [of the history of the drafting of the rules] for the general reason that lawyers might think that what they said was too official."'17

13. Brazil, Hazard, \& Rice, supra note 4, at 319-32.

14. The revised Rules of Practice for the Courts of Equity of the United States, as promulgated by the Supreme Court on Nov. 4, 1912 (to take effect Feb. 1, 1913), are published as an appendix to volume 226 of United States Reports (1913). I cite rules from this source hereafter as 1912 Equity Rules.

15. The Chief Justice probably did not want litigants to be able to use the committee's records to paint the Court into an interpretive corner. It is likely that the Court knew that it could not foresee all the implications of the rules-and wanted to retain sufficient flexibility in interpreting them to minimize problems. The Court also may have wanted to discourage the public from focusing on how much power the Court had in fact delegated to a body (the Advisory Committee) recognized by no statute.

16. According to Joseph F. Spaniol, Jr., Deputy Director, Administrative Office of the United States Courts, only two or three scholars have been permitted to look at the original committee's records, which are preserved in the Federal Records Center. No one has been given permission to quote from these records. There is, however, another source of data about the Advisory Committee's work. Charles E. Clark, reporter to the committee, preserved a substantial body of documents (including verbatim transcripts of some proceedings) from this period of the committee's work. These documents are preserved in Clark's papers at the Sterling Memorial Library, Yale University. See infra note 113 for additional information about these papers.

17. See Charles E. Clark, Fundamental Changes Effected by the New Federal Rules I, 15 Tenn. L. Rev. 551, 555 (1939), where Dean (subsequently Chief Judge) Clark observes:

I might say, as perhaps some of you know, the Supreme Court has suggested that it is undesirable for members of the committee to write books on the subject for the general reason that lawyers might think that what they said was too official. Therefore, what I say to you is entirely unofficial, and cannot be depended on at all. (Laughter.) I believe we can make speeches because everybody knows that what one says in a speech does not count or does not mean anything. 
Despite these early efforts by the Supreme Court to contain the visibility of the views of the committee, by 1940 lower federal courts had begun using both the Advisory Committee notes ${ }^{18}$ and informal public statements by members of the committee as tools to help interpret the rules. ${ }^{19}$ Only a few years later the Supreme Court accepted the inevitable, acknowledging that the intentions of the drafters were relevant factors when construing the rules. Mississippi Publishing Corp. v. Murphree, ${ }^{20}$ decided in early 1946, involved a challenge to Rule 4(f). While addressing that challenge the Court declared that the "fact that this Court promulgated the rules as formulated and recommended by the Advisory Committee does not foreclose consideration of their validity, meaning or consistency. But in ascertaining their meaning the construction given to them by the Committee is of weight." 21 In the next sentences of its opinion the Court began explicating Rule 4(f), relying almost exclusively on explanations that "the authorized spokesmen for the Advisory Committee" had offered during institutes the ABA sponsored in 1938 and 1939 for the purpose of introducing the new rules to practitioners. ${ }^{22}$

The Court never has retreated from these views about the role of the Advisory Committee's expectations. Lower federal courts have followed Murphree's lead, drawing on both committee notes and contemporary statements by the drafters to help answer questions about the meaning of the rules. ${ }^{23}$ As recently as 1980, in Walker v. Armco Steel Corp. ${ }^{24}$ the Supreme Court felt constrained to struggle with the implications of an Advisory Committee note in a case raising basic questions about the effect of Rule 3. Thus it is clear that while the Court is not likely to feel completely bound by the expectations of the drafters, it also will not ignore them.

out that the author was a member of the Advisory Committee but insisting that "for any opinion expressed in this article this author alone is responsible").

18. See Commentary, Use of Notes and Statements of Advisory Committee in Construction of Rules, 1940, 2 Fed. R. Serv. 632, 633, and cases cited supra note 3; id., 3 Fed. R. Serv. 663 and cases cited supra notes 1-2.

19. Id., 2 Fed. R. Serv. 634; id., 3 Fed. R. Serv. 663 and cases cited in note 3.

20. 325 U.S. 438 (1946).

21. Id. at 444.

22. Id. See also supra note 12 and infra note 189.

23. See, e.g., McDowell v. Davies, 96 F. Supp. 301 (E.D. Wash. 1951), where Judge Driver wrote:

The meaning of the rule remains an open problem and since the meaning is not clearly expressed by the language of the rule I shall resort to the same method of solving the problem as that employed by the Supreme Court in the Mississippi Publishing Corporation case, namely, consideration of the construction placed upon the rule by the Advisory Rules Committec. Such construction is stated in the notes of the committee on Rule 64 as follows: "This rule adopts the existing federal law, except that it specifies the applicable state law to be that of the time when the remedy is sought. Under U.S.C.A., Title 28, former $\$ 726$ (Attachments as provided by state laws) the plaintiff was entitled to remedies by attachment or other process which were on June 1, 1872, provided by the applicable state law, and the district courts might, from time to time, by general rules, adopt such state laws as might be in force."

Id. at 303. A footnote added at the end of this passage reads: "3. To the same effect see statement of Committee member Mr. Robert G. Dodge, Cleveland Institute on the Federal Rules 335."

For a more recent example of a court extensively using records of deliberations of the Advisory Committee to help remove doubt about the meaning of one of the Federal Rules of Civil Procedure, see Whalen v. Ford Motor Credit Co., 684 F.2d 272, 274-77 (1982).

24. 446 U.S. 740,750 \& n.10 (1980). 


\section{A. The Historical Evidence}

The historical record makes it abundantly clear that the Advisory Committee's intent in drafting Rule 53 was to preserve the essentials of the system of referencing as it existed under the Federal Equity Rules between 1912 and $1938 .{ }^{25}$ While the committee used the promulgation of the new rule as an opportunity to make modest changes in established practices ${ }^{26}$ and to remove confusion that some of the Equity Rules had generated, ${ }^{27}$ the primary purpose of Rule 53 was to carry forward an existing system..$^{28}$ As the Advisory Committee's original note to Rule 53 indicates, virtually every provision in the new rule was based on a comparable pronouncement in one of the Equity Rules. ${ }^{29}$ And as I will explain in the next section, the transcripts of the Advisory Committee's deliberations show that the committee expected Rule 53 to guide federal courts only when making the kinds of references that had become familiar (but not common) parts of equity practice. Thus, given the primary purpose and sources of Rule 53, it is reasonable to look for evidence about its intended scope by examining the referencing system it inherited and preserved.

\section{Roles of Masters and References Before 1938}

As Linda J. Silberman has ably demonstrated, the American version of the special master system "grew out of early English chancery practice" and was "not derived from the later [English] system of masters at law who render pretrial assistance in civil matters."30 While American courts have

25. For evidence supporting this view see the original Advisory Committee Note to Rule 53, reproduced in 12 Charles Alan Wright \& Arthur R. Miller, Federal Practice and Procedure, 492-93 appendix C (St. Paul, Minn.: West Publishing Co., 1969); statement by Robert G. Dodge (member of the original Advisory Committee) in American Bar Association, supra note 14, at 330-34; statement by Edgar B. Tolman, Secretary of the Advisory Committee on Rules for Civil Procedure, Rules of Civil Procedure for the District Courts of the United States, Hearings Before the House Comm. on the Judiciary, 75th Cong., 3d Sess., Mar. 1-4, 1938, serial 17, at 122 [hereinafter cited as Rules Hearings]; W. Calvin Chesnut, Analysis of Proposed New Federal Rules of Civil Procedure, 22 A.B.A.J. 533, 535 (1936); Dobie, infra note 53, at 291; Daniel K. Hopkinson, The New Federal Rules of Civil Procedure Compared with the Former Federal Equity Rules and the Wisconsin Code, 23 Marq. L. Rev. 159, 179 (1939); Edward H. Hammond, Some Changes in the Preliminary Draft of the Proposed Federal Rules of Civil Procedure, 23 A.B.A.J. 629, 633 (1937); Kaufman, supra note 10, at 454; Silberman, Part II, supra note 1, at 1325 \& nn.161, 162; Nathan, supra note 201, at 424; Cruz v. Hauck, 515 F.2d 322, 329 (5th Cir. 1975).

26. For a description of the differences between Rule 53 and the former Equity Rules, see Charles C. Montgomery, Changes in Federal Practice Resulting from the Adoption of the New Federal Rules of Civil Procedure, 1 F.R.D. 337, 350-51 (1940).

27. Charles E. Clark, The Proposed Federal Rules of Civil Procedure, 22 A.B.A. J. 447, 451 (1936); Dobie, infra note 53, at 291.

28. Because the new rules merged procedures in law and equity, one important effect of Rule 53 was to formally extend the guidelines about referencing to actions at common law. See Hopkinson, supra note 25 , at 179 . Before merger, references in actions at law were based on the courts' inherent power and were guided, loosely, by pronouncements in the cases. See Ex parte Peterson, 253 U.S. 300, 312-13 (1920).

29. Advisory Committee on Rules for Civil Procedure, Notes to the Rules of Civil Procedure for the District Courts of the United States, Note to Rule 53 (1938) (originally published in pamphlet form with the rules), reproduced in 12 Wright \& Miller, supra note 10, at 492-93 appendix C.

30. Silberman, Part II, supra note 1, at 1321-22. Also see, generally, id. Part I, supra note 1, at 1072-1103. 
been appointing masters since the colonial period, ${ }^{31}$ it appears that use of these quasi-judicial officers peaked in the latter half of the nineteenth century and in the first decade of the twentieth. ${ }^{32}$ During this period masters served in at least three different capacities in equitable proceedings in federal court. ${ }^{33}$ One relatively common role consisted of helping judges cope, at the trial, with unusually complex factual issues. Most often such issues involved financial records and relationships. ${ }^{34}$ For example, when the measurement of a competitor's profits would require a painfully time-consuming examination of documents or an expert's penetration of obscure accounting practices, equity courts could call on a master to gather the relevant data and make an initial analysis and recommendation. ${ }^{35}$

31. James R. Bryant, The Office of Master in Chancery: Colonial Development, 40 A.B.A.J. 595 (1954). See also William Wirt Blume, Civil Procedure on the American Frontier, 56 Mich. L. Rev. 161, 194-95 (1957) (alluding to late eighteenth-century territorial laws that contemplated references of matters of account); see also United States v. Manning, 215 F. Supp. 272 (W.D. La. 1963), where Circuit Judge Wisdom, speaking for a three-judge court, described the history of the use of masters thus:

\begin{abstract}
The office of master in chancery, of French origin and imported with the Norman Conquest, is one of our oldest institutions in Anglo-American law. English Chancery Courts, heavy borrowers from the civil law, may have derived the system of special masters from the civilian judex of the Roman Republic and Early Empire. The civil judex ("referee") was a private citizen appointed by the praetor or other magistrate to hear the evidence, decide the issues, and report to the court appointing him. Whatever its origin, the use of masters was a useful tool of English law before the colonization of America. In the colonial development of America "just as chancery relief had been required and had become a part of the judicial system of colonial America, so had the office of master been recognized as an integral part of the administration of that relief and had become soundly rooted in the legal thinking and custom. It was from this basis that after the Revolution the office of master in chancery or its equivalent made its way into many of the state and federal systems of procedure." In most states today a master in chancery is an assistant of the chancellor. He may perform ministerial or judicial acts, but he "acts as the representative of the chancery court, and his official conduct is subject to the court's control and supervision." 19 Am.Jur. Verbo Equity, 251. "Under the Constitution and statutes of some states, a master has the status of a judicial officer * * and all the powers of the court in which the cause is pending." 19 Am.Jur. Verbo Equity, p. 253.
\end{abstract}

Id. at 292-93 (citations omitted).

32. John C. Rose, Jurisdiction and Procedure of the Federal Courts 496 (3d ed. Albany, N.Y.: Matthew Bender \& Co., 1926).

33. The three roles I describe in the text involve (1) reference of a complex part of the liability or relief aspect of an action, (2) reference for initial determination of an entire case, and (3) appointment to supervise an evidentiary deposition or to resolve a discrete dispute about interrogatories posed during such a deposition. For other descriptions and categorizations of masters' roles before 1912 see 3 Simon Greenleaf, A Treatise on the Law of Evidence, Edward A. Harriman ed., $\S \S 332-33$, \& at 317 n.2 (16th ed. Boston: Little, Brown \& Co., 1899); and 2 Chrisenberry Lee Bates, Federal Equity Procedure $\S \S$ 740-46 (Chicago: T.H. Flood \& Co., 1901).

34. Rules 73-84 of the Equity Rules that were in effect between 1866 and 1911 governed "Reference to and Proceedings Before Masters." These rules contained several allusions to matters of account. For example, the first rule in this section, Rule 73, declared: "Every decree for an account of the personal estate of a testator or intestate shall contain a direction to the master to whom it is referred to take the same to inquire and state to the court what parts, if any, of such personal estate are outstanding or undisposed of, unless the court shall otherwise direct." Rule 79 also explicitly contemplated use of masters to help resolve disputes involving accounts: "All parties accounting before a master shall bring in their respective accounts in the form of debtor and creditor; and any of the other parties who shall not be satisfied with the account so brought in shall be at liberty to examine the accounting party viva voce, or upon interrogatories, in the master's office, or by deposition, as the master shall direct." And Rule 81 guided masters who were appointed in contests between creditors. All of these rules are reproduced in Hopkins, supra note 18 , at 126-33.

In Terry v. President of the Bank, 20 F. 777, 781-82 (C.C.W.D.N.C. 1884), the court stated that federal equity courts usually appointed masters to hear disputes about competing claims when creditors were fighting over a fund that was insufficient to pay all debts.

35. See Kimberly v. Arms, 129 U.S. 512, 523 (1889); William S. Simkins, a Federal Equity Suit, 583-84 (2d. ed. Rochester, N.Y.: Lawyers Co-operative Publishing Co., 1911); 2 Bates, supra note 186, $\S \S 792-94,801-27$; John G. Henderson, Chancery Practice 162-63, 189-93 (Chicago: T.H. Flood \& Co., 1904). 
Judges presiding over suits at common law also had access to this kind of assistance. When computing damages threatened to be an intolerably tedious or unusually esoteric exercise, a law court could appoint an expert (called an auditor, examiner, or referee in this context) to do the spade work. ${ }^{36}$ When confined to specific issues and to situations that demanded no exercise of judicial discretion (e.g., ministerial tabulations from documents of undisputed authenticity), these kinds of references seem to have provoked relatively little concern. ${ }^{37}$ This was the traditional and accepted role of the master or auditor.

During the nineteenth century, however, masters also came to play a much larger and substantially more controversial role in some equity proceedings. ${ }^{38}$ Even without the consent of the parties some chancellors asserted a power to delegate responsibility for virtually all aspects of a case to a master. ${ }^{39}$ The master would handle pretrial disputes, hear and report all the evidence, and then recommend a disposition. In such situations it was possible for the judge to play a passive, almost meaningless role. The trial court was supposed to review the master's report and entertain objections to it, ${ }^{40}$ but under this procedure a judge who wanted to could leave the real decision making to the master. ${ }^{41}$

Judges often were not aggressively involved in crucial parts of the litigation process in equity even when they did not formally delegate frontline responsibility for an entire case (or a complex part of it) to a master. Before 1913, adjudication on the equity side of a federal court often was cumbersome, protracted, and expensive. ${ }^{42}$ Pleading could degenerate into a complex and highly ritualized process. ${ }^{43}$ And after litigants emerged from the pleading thicket they often were involved in a long series of evidentiary events designed to build a record sufficient to permit the court, in a final hearing, ${ }^{44}$ to enter a judgment. The process leading to the hearing could in-

36. Ex parte Peterson, 253 U.S. 300,314 (1920); cf. Heckers v. Fowler, 69 U.S. (2 Wall.) 123 (1864) (reference for initial hearing and determination of all issues, with consent of parties).

37. Henderson, supra note 35, at 164-73, 189; Simkins, supra note 35, at 586.

38. See, e.g., Henderson, supra note 35, at 174-77.

39. See Simkins, supra note 35, at 584-85; 2 Bates, supra note 33, at 793-94; cf. Henderson, supra note 35, at 162-63, 169-77. References of entire cases based on the consent of the parties also became more popular in the latter half of the nineteenth century. See Kimberly v. Arms, 129 U.S. 512, 524-25 (1889) (also suggesting that reference of an entire case over the objection of the parties was not normally proper).

40. See Rules 83 and 84 of the Federal Equity Rules in effect between 1866 and 1911 in James Love Hopkins, ed., The New Federal Equity Rules Promulgated by the United States Supreme Court at the October Term 1912, at 132-33 (8th ed. rev. by Byron F. Babbitt, Cincinnati: W.H. Henderson Co., 1933).

41. Cf. 2 Bates, supra note 33, at 794; Simkins, supra note 35, at 602-4; Wallace R. Lane, Federal Equity Rules, 35 Harv. L. Rev. 276, 295-96 (1922).

42. See Ralph W. Breckenridge, The Federal Equity Practice, 5 Ill. L. Rev. [now Nw. U.L. Rev.] 545, 547-50 (1911); Los Angeles Brush Mfg. Corp. v. James, 272 U.S. 701, 706-7 (1927); cf. 3 George Foster Longsdorf, Cyclopedia of Federal Procedure 447-50 \& n.19 (Chicago: Callaghan \& Co., 1928).

43. Bates, supra note 33, at 113-44, 431; Henderson, supra note 35, at 107-26; 1 Roger Foster, Federal Practice, Civil and Criminal 750-80 (6th ed. Chicago: Callaghan \& Co., 1920); Robert W. Millar, The Mechanism of Fact-Discovery: A Study in Comparative Civil Procedure, 32 Ill. L. Rev. [now Nw. U.L. Rev.] 424, 437-50 (1937); Simkins, supra note 35, 265-83, 429-30 (noting, at 266, a trend toward simplification of equity pleading even before 1912).

44. Simkins, supra note 35 , at 581-82. 
clude propounding and responding to interrogatories (often incorporated in pleadings), ${ }^{45}$ producing documents, ${ }^{46}$ and taking testimony from witnesses and parties in the form of evidentiary depositions. ${ }^{47}$ These evidentiary events could take place over a substantial period and in many different locations, ${ }^{48}$ and it was not uncommon for federal judges to play virtually no role in them. Evidentiary depositions, for example, could be taken before examiners, commissioners, ${ }^{49}$ masters, or notaries. ${ }^{50}$ And when a party objected to the interrogatories proposed for a deposition the dispute could be referred to a master. ${ }^{51}$ Thus the third role for masters in equity practice before 1912 involved either overseeing specific evidentiary exercises or helping resolve discrete disputes that arose in the process of developing the evidentiary record. ${ }^{52}$

After the evidence had been accumulated, the judge would evaluate it in the final hearing. At this stage the chancellor often would have before him or her only a written record that had been developed largely (or entirely) outside his or her presence. ${ }^{53}$ Using pleadings, 'answers to interrogatories, authenticated documents, and transcripts of deposition testimony, the chancellor would decide the case. In this scenario, the "final hearing" bore little resemblance to the trial of a suit at common law ${ }^{54}$-indeed, in some cases, the hearing seems to have been something of an anticlimactic exercise.

By the first decade of this century discontent with equity procedure was widespread. The disaffection focused on the system's excessive formalism, its inefficiency, the difficulty courts and litigants had containing and pacing the adjudicatory process, and the fact that the judges (who were ultimately

45. Id. at 286-89, and 1 Bates, supra note 33 , at 123-35.

46. 1 Bates, supra note 33, at 308; cf. Henderson, supra note 35, §§ 198-210.

47. See Rules 67-69 of the Federal Equity Rules in effect between 1866 and 1911 in Hopkins, supra note 40, at 119-22; see also Simkins, supra note 35, at 513-53; 1 Bates, supra note 33, at 445-67.

48. See generally Simkins, supra note 35, at 521-43, 561-63; Breckenridge, supra note 42 , at 548-49; United States v. United Shoe Mach. Co., 198 F. 870, 874 (D. Mass. 1912).

49. See McCabe, supra note 1 , at 345.

50. 1 Bates, supra note 33, at 451-58; Simkins, supra note 35, at 515-20, 549-51.

51. 3 Greenleaf, supra note 33, at 305-6; cf. Zych v. American Car \& Foundry Co., 127 F. 723 (C.C.E.D. Mo. 1904).

52. I have not been able to determine how often, in the period before 1912 , masters were involved in depositions or other evidentiary exercises in cases that did not involve reference of major substantive issues or trial itself.

53. See Reflectolyte Co. v. Edwin F. Guth Co., 31 F.2d 777, 778 (E.D. Mo. 1927), where, during a discussion of Rule 47 of the Equity Rules of 1912 (supra note 14), the court observed:

\footnotetext{
On this point the effect of rule 47 , and other rules which are germane, was to change the practice as to testimony on the trial on the merits of equity actions. Theretofore an equity case was usually heard on the merits on depositions taken before examiners appointed by the court. The oral examination of a witness in open court on final hearing in an equity case was, before the adoption of the present rules in equity, the exception and not the rule or practice. This practice then applied to witnesses, whether they were within or without the provisions of section 863, Revised Statutes.
}

See also Armistead M. Dobie, Handbook of Federal Jurisdiction and Procedure 716 (St. Paul, Minn.: West Publishing Co., 1928); 7 William J. Hughes, Federal Practice, Jurisdiction and Procedure 242-60 (St. Paul, Minn.: West Publishing Co., 1931); 2 Bates, supra note 33, at 724-27; Simkins, supra note 35, at 556-57; Rose, supra note 32, at 491-92; Charles E. Clark \& Ferdinand F. Stone, Review of Findings of Fact, 4 U. Chi. L. Rev. 190, 204 (1937).

54. 3 Longsdorf, supra note 42, at 902-3, 909-12. 
responsible for deciding issues of fact) often did not see the witnesses and hear the testimony on which key disputes turned. ${ }^{\text {ss }}$ A reform movement finally bore fruit when, on November 4, 1912, the Supreme Court promulgated revised Rules of Practice for the Courts of Equity of the United States. ${ }^{56}$ These rules, which took effect February $1,1913,{ }^{57}$ made dramatic changes in modes of pleading and proof. ${ }^{58}$ They sought to simplify and shorten pleadings ${ }^{39}$ to separate discovery into a distinct ${ }^{60}$ and containable ${ }^{61}$ process, and, perhaps most important, to force the judges back into the central adjudicatory role. ${ }^{62}$ The reformers wanted the judges to reassert direct control over most aspects of equity proceedings ${ }^{63}$ and to greatly reduce the roles that quasi-judicial officers, especially masters, had come to play in the equity system. Toward these ends, the rules were designed to pressure the judiciary to assume direct responsibility for discovery disputes, ${ }^{64}$ to force as much of the adjudicatory action as possible into the trial (final hearing) itself, and to prohibit the judges from routinely assigning frontline responsibility for major parts of that final stage to masters or other inferior officers. ${ }^{65}$

New Rule 46 announced that henceforth the normal mode of receiving evidence from witnesses would be oral testimony in open court before a judge ${ }^{66}$ not through transcripts of evidentiary depositions taken earlier before a master, commissioner, or notary. ${ }^{67}$ The rule phrased it this way: "In

55. Breckenridge, supra note 42, at 546-50; Wallace R. Lane, One Year Under the New Federal Equity Rules, 27 Harv. L. Rev. 629, 630-34 (1914) Thereinafter cited as Lane, One Year]; id., Twenty Years Under the Federal Equity Rules, 46 Harv. L. Rev. 638, 640 (1933) Thereinafter cited as Lane, Twenty Years]; 3 Longsdorf, supra note 42, at 445-50, 902-3; cf. Los Angeles Brush Mfg. Corp. v. James, 272 U.S. 701, 706-7 (1927).

56. 226 U.S. 627 (1912).

57. 226 U.S. 629 (1912).

58. Dixie Drinking Cup Co. v. Paper Utils. Co., 5 F.2d 322, 323-24 (E.D.N.Y. 1925); Rose, supra note 32, at 483-92; Dobie, supra note 53, at 716; Alexander Holtzoff, New Federal Procedure and the Courts 4 (Chicago: American Bar Association, 1940).

59. Rose, supra note 32, at 483-84; 3 Longsdorf, supra note 42, at 446-71; Lane, One Year, supra note 55, at 634-35.

60. Luten v. Camp, 221 F. 424, 427 (E.D. Pa. 1915); Dobie, supra note 53, at 723, 728; 1 Foster, supra note 43, at 752-54; Millar, supra note 43, at 449-50.

61. Under new Equity Rule 56, cases were automatically forced onto the trial calendar after the periods for taking evidentiary depositions (as prescribed by Rule 47) expired. Rule 57 attempted to attack procrastination by counsel and court by limiting continuances. 226 U.S. 664-65 (1912). See also Lane, One Year, supra note 55, at 629-30, and id., Working Under Federal Equity Rules, 29 Harv. L. Rev. 55, 71-72 (1915) thereinafter cited as Lane, Working].

62. I say "back" into the central adjudicatory role because the reformers in 1912 believed that the major changes affected by the new rules would reestablish the practices of the period prior to promulgation of the equity rules of 1842. See 7 Hughes, supra note 53, at 242-44; 3 Longsdorf, supra note 195, at 909-12; Hopkins, supra note 40, at 249-50; Clark \& Stone, supra note 53, at 203-4.

63. See Computing Scale Co. v. Toledo Computing Scale Co., 279 F. 648, 672 (7th Cir. 1921); Breckenridge, supra note 42, at 545; cf. Lane, supra note 41, at 278-79.

64. See 1912 Equity Rules 51 and 58, supra note 14, at 663, 665-66; Luten v. Camp, 221 f. 424 (E.D. Pa. 1915); Dixie Drinking Cup Co. v. Paper Utils. Co., 5 F.2d 322 (E.D.N.Y. 1925); Dobie, supra note 53, at 721, 724.

65. See 1912 Equity Rule 59, supra note 14, at 66, discussed infra at pp. 155-56.

66. See id. Rules 46 and 47, at 661-62; Rose, supra note 32, at 491-92.

67. Los Angeles Brush Mfg. Corp. v. James, 272 U.S. at 706-7; Dobie, supra note 53, at 716; 2 Longsdorf, supra note 42, at 748-49; 3 id. at 902-3, 909; W. S. Simkins, Simkins Federal Practice, 709-10, (rev. ed. by Alfred J. Schweppe, Rochester, N.Y.: Lawyers Cooperative Publishing Co., 1934); cf. Anchor Brewing Co. v. U.S., 5 F.2d 883 (3d Cir. 1925); North v. Herrick, 203 F. 591 , 592 (N.D.N.Y. 1913). 
all trials in equity the testimony of witnesses shall be taken orally in open court except as otherwise provided by statute or these rules." 68 The phrase "as otherwise provided by statute" referred to federal legislation that authorized taking evidentiary depositions in a limited set of circumstances. ${ }^{69}$ The Equity Rules themselves added little, if anything, to the statutory authorization. They contained only one independent provision for depositions: Rule 47, which was entitled "Depositions-To Be Taken In Exceptional Circumstances." 70 This rule merely declared that parties could take evidentiary depositions when they were entitled to do so by federal statute or when they could show "good and exceptional cause for departing from the general rule"11 (i.e., the rule that testimony normally should be taken in open court, at trial, before the judge). Since the federal statutes already authorized taking evidentiary depositions when witnesses were unavailable for trial because they lived beyond subpoena range, or were aged or infirm, ${ }^{72}$ or when such depositions were "necessary, in order to prevent a failure or delay of justice," 73 Rule 47 seems to have had no meaningful effect on the scope of preexisting judicial powers. A litigant who could satisfy the new rule by showing "good and exceptional cause for departing from the general rule" undoubtedly could satisfy the requirements of at least one of the statutes. ${ }^{74}$

The 1912 revisions of the Equity Rules also reduced parties' incentives to have testimony taken outside of court (in the form of a deposition) by making it clear that objections to questions or testimony in such proceedings had to be presented "in short form" and that "no transcript filed by any such officer shall include argument or debate." "Made imperative by the abuse of the old rule," 76 this change substantially limited lawyers' ability to use such examinations as occasions to build elaborate legal and factual arguments into a record they expected a court ultimately to review.

Thus new Rules 46,47 , and 51 worked in tandem to discourage counsel from taking evidentiary depositions and thereby sharply cut back the extent to which masters might be involved in the process of preparing disputes for a final hearing before a chancellor. ${ }^{77}$ While evidentiary depositions continued to be taken, ${ }^{78}$ and while masters were among the officers permitted

68. 1912 Equity Rule 46, supra note 14 , at 661 .

69. I discuss these statutes infra at p. 156. See also Dern v. Tanner, 60 F.2d 626, 627 (D. Mont. 1932); Iowa Washing Mach. Co. v. Montgomery Ward \& Co., 227 F. 1004, 1007 (S.D.N.Y. 1915).

70. 1912 Equity Rule 47, supra note 14, at 661-62.

71. Id.

72. Former 28 U.S.C. $\S 639$ (West compact ed., as amended through Dec. 3, 1928).

73. $1 d, \& 644$.

74. See, e.g., M. Whitmark \& Sons v. Calloway, 22 F.2d 412, 414 (E.D. Tenn. 1927).

75. 1912 Equity Rule 51 , supra note 14 , at 663 .

76. Hopkins, supra note 40 , editor's note at 259.

77. 3 Longsdorf, supra. note 42 , at $940-41$.

78. Reflectolyte Co. v. Edwin F. Guth Co., 31 F.2d 777, 778 (E.D. Mo. 1927); Lane, Working, supra note 61 , at 70-71. 
to preside over them, ${ }^{79}$ the historical record suggests that after 1912 federal courts confined use of special masters almost exclusively to conventional references of complex matters at the trial stage.

Conventional references, however, also were a primary target of the equity reformers. The reformers believed that trial-stage references often needlessly added substantial costs (the parties paid for the master's service) and delay to the adjudicatory process. ${ }^{80}$ Critics also charged that masters frequently were unable to exercise a restraining influence over proceedings before them, thus permitting records and fees to swell far beyond justifiable limits. ${ }^{81}$ One obvious way to attack these problems was to force the judges to retain direct responsibility for the entire adjudicatory process and to preside over the taking of evidence as much as possible. ${ }^{82}$ This solution also helped quell a concern that some courts were using references to masters as a means to escape their decision-making responsibilities and thus were depriving litigants of their right to have their disputes fully aired in the presence of the ultimate fact-finder. ${ }^{83}$

As indicated above, similar concerns had inspired the reformers to insist that the testimony of witnesses be taken "orally in open court" except when fairness required the use of some other mode. It was clear, however, that this new norm could not become reality if established reference practices were permitted to continue. Thus a basic change in the rules governing references had to be made in tandem with the reforms in the procedures for taking evidence. ${ }^{84}$ New Rule 59 completed the integrated transformation of the system by announcing that henceforth, "[s]ave in matters of account, a reference to a master shall be the exception, not the rule, and shall be made only upon a showing that some exceptional condition requires it."8s

In combination, the reforms just described were designed to telescope most of the marshaling of evidence and most of the decision making in equity into compact trials that normally were presided over in their entirety by judges. Under the new system, masters played a role that was at once substantially more limited and more clearly defined than it had been. Masters were not to be involved in the normal procedures for taking evidence and for resolving disputes about the propriety of questions posed during examinations. Instead, courts would use masters primarily, if not exclusively, to render well-focused assistance with specific issues, especially in computing damages or sorting out complex accounts. While there were some com-

79. See 1912 Equity Rule 52, supra note 14, at 663; Lane, Working, supra note 61, at 71; Simkins, supra note 67 , at 713-14, 733-49.

80. Los Angeles Brush Mfg. Corp. v. James, 272 U.S. at 706-7; Rose, supra note 32, at 498.

81. See Rollman Mfg. Co. v. Universal Hardware Works, 229 F. 579, 580-81 (E.D. Pa. 1916); North v. Herrick, 203 F. 591 , 592 (N.D.N.Y. 1913); Henderson, supra note 35, at 174-77; cf. Lane, supra note 41 , at 296; and id., Twenty Years, supra note 55, at 642-43, 654-55.

82. Cf. Computing Scale Co. v. Toledo Computing Scale Co., 279 F. 648, 672-73 (7th Cir. 1921).

83. Cf. Lane, supra note 41, at 296; Cruz v. Hauck, 515 F.2d 322, 329-30 (5th Cir. 1975). The source and scope of this presumed "right" is unclear.

84. Los Angeles Brush Mfg. Corp. v. James, 272 U.S. at 706-7.

85. 1912 Equity Rule 59, supra note 14, at 666. 
plaints after 1912 that some judges interpreted the exceptional condition requirement too loosely and ordered references too often, ${ }^{86}$ it appears that most federal courts abided by the spirit of the new rules and used masters sparingly. ${ }^{87}$

One additional aspect of the historical backdrop against which the Federal Rules of Civil Procedure were drafted remains to be explored. If in the decades immediately preceding 1938 it had been relatively common for federal judges (sitting in law or equity) to involve masters (or equivalent officers with different titles) in pretrial discovery matters, then there might be room to argue that the Advisory Committee, the Supreme Court, and Congress intended Rule 53 to silently authorize the continuation, and perhaps even the expansion, of this practice. ${ }^{88}$ The historical record, however, does not lend itself to any such interpretation. ${ }^{89}$ Instead, it appears that masters did not play a significant role in discovery in federal courts between 1912 and 1938.

The discovery system was not well developed in federal court prior to 1938. On the law side of the federal system there was relatively little "discovery" as that term is used today. ${ }^{90}$ With one limited exception, ${ }^{91}$ there were no rules or statutes that permitted parties to explore (before trial) how an opponent planned to approach his or her case or the evidentiary underpinnings of his or her position. ${ }^{92}$ There were, however, two federal statutes that prescribed circumstances under which litigants could depose witnesses, or other parties, before trial.

It is important to emphasize that these statutes authorized the taking of depositions only to acquire evidence for use at trial. Such depositions were not to be used simply to learn what witnesses or parties who would appear at trial would say, to assess their credibility, or to assay the evidence that

86. See Lane, Working, supra note 61, at 59; id., supra note 41, at 291, 296-97; and id., Twenty Years, supra note 55, at $642-43,652,654$.

87. Cf. North v. Herrick, 203 F. 591,592 (N.D.N.Y. 1913); Anchor Brewing Co. v. U.S., 5 F.2d 883 (3d Cir. 1925); Lane, Twenty Years, supra note 55, at 654-55.

88. Since the Federal Rules of Civil Procedure authorized a substantial expansion of discovery practice, if Rule 53 authorized delegation of responsibility for discovery to masters, it would be arguable that the Advisory Committee foresaw an expansion of masters' roles in this arena. As I suggest in the next section, however, the drafters of the rules apparently did not expect federal judges to involve masters in the discovery stage.

89. As the footnotes accompanying the text in this section indicate, my impressions about discovery and the roles masters played in civil actions prior to 1938 are based largely on secondary sources, including contemporary treatises on federal practice, law review articles, and reported cases. I have made no effort to examine firsthand the administrative or docket records of federal courts from this period. Nor have I tried to interview litigators who practiced in federal courts before 1938.

90. Some commentators have gone so far as to suggest that there was virtually no discovery in suits at common law in federal courts before 1938. See, e.g., Judith Resnick, Managerial Judges, 96 Harv. L. Rev., 374, 392 (1982); George Ragland, Jr., Discovery Before Trial 269 (Chicago: Callaghan \& Co., 1932); Edson R. Sunderland, The New Federal Rules, 45 W. Va. L.Q. 5, 19-20 (1938). As the discussion in the text will suggest, I believe that these generalizations overstate the matter.

91. The exception was the equitable bill of discovery, which at least in theory remained available to litigants in suits at common law in federal courts. See Simkins, supra note 67, at 95. I describe the preconditions for resorting to this device, and the scope of its utility, in the text at pp. 158-60 infra.

92. Simkins, supra note 67 , at 99-100, 768. 
supported competing views of the facts..$^{93}$ Of course, the purposes and results of a given litigant's use of these devices could not be tidily contained, and some efforts to secure proof for trial no doubt also resulted in some "discovery" of how an opponent would present his case. At least in theory, however, discovery of this kind of information was merely an incidental byproduct of procedures designed to secure other ends. ${ }^{94}$

The extent of the use of the deposition procedures authorized by the federal statutes is unclear. ${ }^{95}$ It does seem clear, however, that quasi-judicial officers comparable to the special masters of today generally did not play a significant role in the deposing process. Because the phrase "special master" was attached only to appointees serving in equity proceedings, the cases and commentary that discuss depositions in suits at law rarely mention masters. ${ }^{96}$ Law courts, however, did have the authority to appoint persons learned in the law to perform a wide variety of administrative and quasijudicial tasks. Such appointees were referred to without great consistency or precision under a variety of titles, including commissioners, magistrates, examiners, referees, and auditors. ${ }^{97}$ At least after the First World War, however, the officers before whom depositions were taken rarely were lawyers appointed on an ad hoc basis and vested with the power to make rulings on procedural disputes. The evidence suggests that by the 1920s depositions in federal actions usually were taken before a notary public and were not attended by any other representative of the court.

There was authority for a federal court to permit depositions to be taken in the manner prescribed by the laws of the state in which the federal court was located. ${ }^{98}$ In most states, however, depositions were "almost always"' taken before "reporters and stenographers who were notaries public.""99 And except in a few states, ${ }^{100}$ notaries taking depositions were essentially

93. Id. at 750-51, 776; Sunderland, supra note 90, at 19.

94. Sunderland, supra note 90 , at 19.

95. Ragland's study of discovery, supra note 90 , described the federal statutes that provided for evidentiary depositions but made no effort to systematically measure the frequency of their use. See id. at 269-70. I know of no effort to assess empirically how extensively depositions or discovery devices were used before 1938.

96. One exception is Zych v. American Car \& Foundry Co., 127 F. 723 (C.C.E.D.Mo. 1904). This case initially was filed in state court in Missouri, where a statute provided that courts could appoint a "special commissioner" to preside at and resolve disputes arising in a deposition. See Res. Mo. $\$ 1759$ (1929) and its precedessor, Res. Mo. \$2136 (1885). In Zych, the court concluded that a federal statute authorized the federal court to adopt this state procedure. See former 28 U.S.C. $\$ 643$ (1928), supra note 72.

97. See, e.g., 2 Longsdorf, supra note 42, at 782-78, 814; 6 Hughes, supra note 53, at 472-82.

98. See McLennan v. Kansas City, St. J. \& C.B.R., 22 F. 198 (C.C.S.D. Iowa 1884).

99. Ragland, supra note 90 , at 98.

100. Missouri, New Hampshire, Nebraska, and Ohio empowered notaries to compel answers by attachment for contempt. Ragland, supra note 90, at 110. In New York, Rule 142 of the Rules of Civil Practice provided for the appointment of a "Referee to superintend discovery or inspection." Under this rule, such an appointee could be ordered to "direct and superintend" the discovery event, and his certification of it was deemed presumptive "evidence of compliance or non-compliance with the order" compelling the discovery. See Perlie P. Fallon, The Production, Discovery and Inspection of Written Evidence in New York, 17 Cornell L.Q. 248, 250 n.10 (1932). 
powerless functionaries who had no authority to rule on contested matters or to compel answers. ${ }^{101}$

Only Wisconsin and Missouri had established procedures under which judges could appoint lawyers to supervise depositions and could grant such appointees the power to resolve (subject to a right to appeal) disputes about questions being posed. In Missouri, however, litigants rarely took advantage of this device; instead, they usually relied on the less expensive services of "notaries or other officers not learned in the law." In Wisconsin the state courts appointed "commissioners" to preside over depositions. In larger urban areas these commissoners were attorneys, but in smaller towns they often were merely former court reporters. ${ }^{102}$ Apparently such commissioners were routinely present at depositions in matters filed in the state's courts. It is not clear whether this practice penetrated federal courts located in Wisconsin, but I have found no evidence that federal courts sitting in other states adopted any comparable procedure.

Litigants in suits at common law in federal courts could file in the district court, sitting in its equitable capacity, a bill of discovery in aid of an action at law. ${ }^{103}$ While federal courts had no power to order depositions under such bills, ${ }^{104}$ they could grant a request to compel a party to produce documents for inspection and copying before trial. ${ }^{105}$ Moreover, bills of discovery were the only means by which a litigant in an action at law could compel an opponent to respond to interrogatories during the pretrial period. ${ }^{106}$

The evidence suggests, however, that most federal courts viewed an equitable bill of discovery as an extraordinary device that should be authorized only if a party could show that unless she could serve interrogatories or inspect documents before trial her ability to present her case would be substantially prejudiced or the trial itself would be disrupted. ${ }^{107}$

101. Ragland, supra note 90 , at $97-100,104$.

102. Ragland, supra note 90 , at 104-6.

103. See Sinclair Ref. Co. v. Jenkins Petroleum Process Co., 289 U.S. 689 (1933); Pressed Steel Car Co. v. Union Pac. R., 240 F. 135 (S.D.N.Y. 1917); 2 Foster, supra note 43, at 1750-54.

104. See Judge Learned Hand's second opinion in Pressed Steel Car Co. v. Union Pac. R., 241 F. 964, 967 (S.D.N.Y. 1917), where he observed:

The plaintiff will have leave to frame and keep reframing interrogatories till it has extracted from the defendant all the information which it possesses. Much the most convenient way would be for the parties to agree upon a master and allow the plaintiff an oral examination. This, however, I cannot compel; but the same result may probably be obtained, though it must be confessed with the maximum of expense in time and labor, by allowing interrogatories to be renewed as often as justice requires. If that does not serve, the plaintiff must rely upon such rights as he will have at the trial under Revised Statutes, $\$ 724$ (Comp. St. 1916, $\$ 1469$ ).

Neither the reported cases nor the treatises I have consulted suggest that parties commonly agreed to a deposition procedure like the one proposed by Judge Hand.

105. See 3 Longsdorf, supra note 42, at 898-99; Simkins, supra note 67, at 94-95.

106. Cf. Bradford v. Indiana Harbor Belt R., 300 F. 78 (7th Cir. 1924).

107. In Sinclair Ref. v. Jenkins Petroleum Process Co., 289 U.S. 689 (1933), the Supreme Court, speaking through Justice Cardozo, seemed to approach a request for a bill of discovery in a much more liberal spirit than was reflected in other opinions on the subject. See, e.g., Bradford v. Indiana Harbor Belt R., 300 F.78 (7th Cir. 1924); 2 Foster, supra note 43, at 1753-54; 3 Longsdorf, supra note 42, at 898-99.

Cardozo's relative liberality anticipated the spirit of the discovery provisions that were incorporated five years later into the Federal Rules of Civil Procedure. His attitude may have been in part a product of experience with the provisions for discovery in New York. 
In part as a result of this judicial inhospitality, and in part as a result of the strict limitations some courts imposed on the kinds of information a party could compel an opponent to disgorge in response to a bill of discovery, ${ }^{108}$ litigants did not often seek to employ this rather cumbersome means of acquiring information. ${ }^{109}$ Moreover, it seems that federal courts rarely involved special masters in the process by which discovery was conducted under such bills.

My impression from reported opinions and contemporary treatises is that in the vast majority of cases involving bills of discovery, the interrogatories were answered or the documents were produced directly to the requesting party and no master was utilized. If this impression accurately reflects actual practice before 1938, the drafters of the Federal Rules of Civil Procedure would not have had before them precedents in which masters were used in connection with bills of discovery, and therefore an argument that the drafters silently intended Rule 53 to perpetrate a well-established tradition would flounder, lacking such tradition. ${ }^{110}$

Nor does it appear that special masters were involved to any significant extent in the separate procedures for discovery that were provided in Rule 58 of the Equity Rules of 1912 . That Rule provided that the judge was to settle disputes about interrogatories and requests for documents and I have found only one reported case from the period between 1912 and 1938 that even mentions using a master in connection with a document production. ${ }^{111}$ Thus it appears that discovery under Rule 58 usually was conducted directly between the parties and that if the aid or intervention of a neutral officer was required, a judge was far more likely than a special master to have provided it.

If my inferences about modes of practice during discovery and at trial are

108. Under traditional views, a party responding to interrogatories served under a bill of discovery in aid of an action at law generally would be required to disclose only ultimate facts (as opposed to mere evidence) and only those facts which the discovering party needed (but could not otherwise acquire) in order to prove his case or to establish his affirmative defense. Bills of discovery could not be used to gather information about how an opponent intended to prove his case. See Sinclair Ref. Co. v. Jenkins Petroleum Process Co., 289 U.S. 689, 697 (1933), cf. Carpenter v. Winn, 221 U.S. 533, 540 (1911); Durant v. Goss, 12 F.2d 682, 683 (6th Cir. 1926); Galion Iron Works Co. v. Ohio Corrugated Culvert Co., 244 F. 427 (6th Cir. 1917); General Film Co. v. Sampliner, 232 F. 95 (6th Cir. 1916); Window Glass Mach. Co. v. Brookville Glass \& Tile Co., 229 F. 833 (W.D. Pa. 1916).

109. See Pressed Steel Car Co. v. Union Pac. R., 240 F.135, 136-37 (S.D.N.Y. 1917); cf. Walter C. Clephane, Handbook of the Law of Equity Pleading and Practice, 66, 80-81, 92-93 (St. Paul, Minn.: West Publishing Co., 1926). There were, however, several reported cases in the two decades before adoption of the Federal Rules of Civil Procedure in which such bills of discovery were successfully employed. See, e.g., Sinclair Ref. Co. v. Jenkins Petroleum Process Co., 289 U.S. 689 (1933); Baush Mach. Tool Co. v. Aluminum Co. of Am., 63 F.2d 778 (2d Cir. 1933); Zolla v. Grand Rapids Store Equip. Corp., 47 F.2d 611 (S.D.N.Y. 1930); Trophy Tower Sales Corp. v. Gillette Safety Razor Co., 5 F. Supp. 900 (S.D.N.Y. 1934); Puget Sound Navigation Co. v. Assoc. Oil Co., 56 F.2d 605 (W.D. Wash. 1932).

110. The cases cited in supra note 109 indicate that disputes about discovery under equitable bills were not referred to masters but were taken directly to the trial court for resolution. I also should emphasize that under Rule 51 of the 1912 Federal Equity Rules, supra note 12, the examiner or officer before whom a deposition was taken had no power to rule on "the competency or materiality or relevancy of the questions." This rule presumably did not apply directly to bills of discovery in aid of actions at law, as depositions could not be ordered under such bills.

111. Pressed Steel Car Co. v. Union Pac. R. Co., 240 F. 135, 137 (S.D.N.Y. 1917). 
correct, in the two decades prior to 1938 federal courts used special masters to a significant extent only in the conventional trial-stage references that were contemplated in Equity Rules 59 through $68 .{ }^{112}$ The fact that this was the only readily visible use of masters in the federal system in this period reinforces the conclusion that in 1938 neither the Advisory Committee nor the Supreme Court viewed Rule 53 as authorizing federal judges to delegate responsibility for discovery disputes to special masters.

\section{The Proceedings of the Original Advisory Committee}

The remaining historical evidence about the reach of Rule 53 consists of the records of the original Advisory Committee's deliberations. These records show that the Committee did not expect Rule 53 to authorize or limit references of discovery tasks to masters.

The transcripts and minutes of the proceedings of the Advisory Committee, ${ }^{113}$ read in tandem with the rules the Committee developed, ${ }^{114}$ reveal that

112. 1912 Equity Rules $59-68$, supro note 14 , at $666-69$.

$\mathrm{My}$ inference that in this period masters were used only for conventional, trial-stage references is supported by a statement submitted by Challon B. Ellis to the Committee on the Judiciary of the United States House of Representatives during hearings about the proposed Federal Rules of Civil Procedure. Discussing proposed Rule 16 (about pretrial conferences), Ellis said:

Such a rule is likely to increase rather than diminish the expense of trial. It is suggested in defense of this rule, that it will be, in actual practice, administered through the appointment in each case of a master to call the parties together to say "what it is all about" and discuss the defects in their pleadings and their plans for conducting the trial before the court. It is said, as we understand it, that this is the way such a practice is carried on in England and that the judge will thus be relieved of the burdens that are imposed upon him.

Such a simple way out of the matter may well be questioned. There is nothing in the rules authorizing the master to take the place of the judge, except in case of the regular well-known reference of the entire case or a part of it, to take testimony, state an account, etc. But suppose there is this simple way out. The master has to be paid; why should the attorneys have to pay a master to hear their discussions about the pleadings when the judge is already paid a salary to do this very thing in open cour. If every case may be referred to a master, even without the will of the parties, we have greatly increased the expense of a trial of law suits. The parties are entitled to a decision by a court and they are not to be remitted to trial and decision by some individual not having the responsibility of a judge.

The familiar procedure of appointment of masters under certain circumstances and in any certain cases is hedged about by all kinds of restrictions and necessary protections. A master does not decide a case; he takes the place neither of the judge nor the jury; he simply hears for certain limited purposes certain testimony and makes a report of such testimony to the court. This is particularly true in a law case and even in an equity case, any action taken by the master, however broad his powers, does not preclude the consideration of the same evidence, the same objections, the same applications by the court.

Rules Hearings, supra note 25.

113. Records of the deliberations of the Advisory Committee have been preserved in several places. One is the Federal Records Center in Suitland, Maryland. The materials there collected have not been organized or digested but are substantial in volume (some 50 cartons) and include at least some transcripts of Advisory Committee meetings. These materials were placed under seal by Chief Justice Charles Evans Hughes in 1938 and remain inaccessible to the general public. Scholars who wish to examine these papers must first secure permission from the Chief Justice of the United States Supreme Court. To date, no scholar has been permitted to quote any portion of these records.

A second source of records of Advisory Committee deliberations is more accessible and usable. The Charles E. Clark Papers are preserved in the Manuscripts and Archives Division of the Sterling Memorial Library at Yale University. These papers have been well organized and inventoried. They include some 38 boxes of materials relating to Judge Clark's service on the Advisory Committee between 1935 and 1956. These materials include transcripts and minutes of the committee's proceedings, suggestions received by the committee, correspondence, abstracts, reports, and memoranda, as well as tentative and preliminary drafts of rules. This collection represents an extremely valuable research source for scholars interested in the history of the Federal Rules of Civil Procedure. A Register of the Clark Papers (Manuscript Group Number 1344) was completed in March 1982 and is available from the Manuscripts and Archives Division of the Sterling Memorial Library. I cite these papers in subsequent footnotes as 
the committee actively considered the pros and cons of authorizing a limited role for masters during the discovery stage, tentatively proposed a rule that would have permitted courts to appoint masters to preside at depositions of adverse parties, and then decided to withdraw any such authorization and to use Rule 53 only to guide conventional, trial-stage references.

Charles E. Clark, then dean of the Yale Law School, was the reporter to the Advisory Committee. ${ }^{115}$ The records of the committee's deliberations that he preserved ${ }^{116}$ show that the first, unpublished draft of the rules that the committee eventually combined to form Rule 53 did not mention any possible use of masters in connection with pretrial discovery. ${ }^{117}$ As originally formulated, the proposed rules about masters consisted essentially of restatements of provisions from the Federal Equity Rules of 1912.

The first allusion to discovery in connection with rules about references appears in the form of a question, written in longhand and pencil (presumably by Clark), beneath Rule 90 of the First Tentative Draft. That rule, based in large measure on Equity Rule 59, declared that a reference to a master should be the exception and not the rule (save in matters of account), and then set forth some basic procedural guidelines for the conventional, trial-stage use of masters. ${ }^{118}$ The question in pencil beneath the rule is: "Should some reference to discovery masters be made?" Right beneath this question there is a response to it, also in pencil but apparently not written at

Clark Papers. All of the materials about committee proceedings that I discuss or quote in this article are from the Clark Papers.

Less complete collections of documents from the Advisory Committee's work are described in Stephen B. Burbank, The Rules Enabling Act of 1934, 130 Penn. L. Rev. 1015, 1132-33 n.529 (1982).

114. The Advisory Committee published two preliminary drafts of the proposed rules, one in May 1936 and the second in April 1937. These drafts were published in pamphlet form and circulated within the profession for comment. See Advisory Committee on Rules for Civil Procedure, Preliminary Draft of Rules of Civil Procedure for the District Courts of the United States and the Supreme Court of the District of Columbia (May 1936) [hereinafter cited as Preliminary Draft]; Report of the Advisory Committee on Rules for Civil Procedure, Proposed Rules of Civil Procedure for the District Courts of the United States (April 1937) [hereinafter cited as Proposed Rules].

After receiving comments and suggestions, the committee made many changes (primarily in form) in the Proposed Rules. These changes were incorporated in a Final Report of the Advisory Committee on Rules for Civil Procedure (published in pamphlet form in Nov. 1937) [hereinafter cited as Final Report].

During the course of its deliberations the committee also considered several unpublished tentative drafts of the rules, especially in late 1935 and early 1936, before it published the Preliminary Draft.

115. Appointment of Committee to Draft Unified System of Equity and Law Rules, Order, ch295 U.S. 774, 775 (1935) [hereinafter cited as Order of Appointment]. Clark subsequently become chief judge of the United States Court of Appeal for the Second Circuit.

116. See supra note 113.

117. See Rule 90 et seq. (Tent. Draft I, unpublished Oct. 25, 1935), Box 97, Clark Papers, supra note 113.

118. The full text of proposed Rule 90, and the note accompanying it, read as follows:

Rule 90. Reference to Master-Exceptional, Not Usual. Save in matters of account, a reference to a master, which in these rules includes a referee or an auditor shall be the exception, not the rule, and shall be made in jury cases only to simplify the issues where such are complicated, and in non-jury cases only upon a showing that some exceptional condition requires it. When such a reference is made, the party at whose instance or for whose benefit it is made shall cause the order of reference to be presented to the master for a hearing within twenty (20) days succeeding the time when the reference was made, unless a longer time be specially granted by the court; if he shall omit to do so, the adverse party shall be at liberty forthwith to cause proceedings to be had before the master, at the costs of the party procuring the reference.

Note. See Equity Rule 59.

Id. 
the same time. ${ }^{119}$ That response reads: "Probably not, Sunderland covers it." 120

The Sunderland alluded to here is Edson R. Sunderland, who was professor of law at the University of Michigan, a member of the Advisory Committee, ${ }^{121}$ and the principal drafter for the committee of the rules to govern the new system of pretrial discovery. ${ }^{122}$ To understand the allusion in this penciled note to Sunderland covering "discovery masters" it is necessary to examine the Advisory Committee's deliberations about the kinds of procedures to establish for discovery under the new, integrated Federal Rules.

The transcripts of the Advisory Committee's proceedings support two important generalizations: a majority of the committee favored establishing a broad and open discovery system, but there was considerable anxiety among some members that the tools of discovery would be abused, primarily by attorneys representing plaintiffs, to harass opponents or to fish for evidence of nonexistent causes of action. ${ }^{123}$ George W. Wickersham, president of the American Law Institute ${ }^{124}$ and vice-chairman of the Advisory Committee until his death in $1936,{ }^{125}$ was among the most vocal in demanding that the new rules include effective means for curbing such potential abuses. Toward this end, Wickersham suggested (in a meeting in November 1935) that the new rules provide for the appointment of standing masters who could, among other things, preside over pretrial depositions. When another member asked the committee to consider the feasibility of using standing masters as they were used in England to help set up cases for trial, Wickersham interjected that he would propose, when the committee turned its attention to "the question of examination before trial, and discovery," that the new rules require that depositions be taken "in the presence of some judge or officer having the power to rule on evidence." ${ }^{126} \mathrm{He}$ immediately added: "There you have a use for a standing master."' 127

Wickersham's was by no means the only voice expressing concern about possible abuses of discovery. Other members of the committee reported that some elements of the bench and bar vigorously opposed the kind of liberalized discovery system that Sunderland's early drafts of discovery rules would establish. ${ }^{128}$ These reports and Wickersham's protests convinced

119. My inference that the response was not written at the same time as the question is based on the fact that the pencil lines in the response are much sharper and thinner than the lines in the question, suggesting that a different (or at least sharpened) pencil was used to write the response.

120. Rule 90, supra note 117.

121. Order of Appointment, supra note 115.

122. See Report of the Advisory Committee in Proposed Rules, supra note 114, at vii.

123. See, e.g., comments by Robert G. Dodge, of Boston, in vol. 3, pp. 730-31, Proceedings for Feb. 22, 1936, Folder 10, Box 95, Clark Papers, supra note 113.

124. Order of Appointment, supra note 115.

125. Id.; Order of Jan. 17, 1938, Re Rules of Procedure, 302 U.S. 783-84 (1938). Wickersham had been attorney general of the United States in the Taft administration. He died Jan. 25, 1936. See 1 Who Was Who in America, 1897-1942, at 1342.

126. Vol. 1, p. 252, Proceedings for Nov. 4, 1935, Box 94, Clark Papers, supra note 113.

127. Id.

128. See, e.g., comments by Robert G. Dodge in Proceedings for Feb. 22, 1936, supra note 123. 
former Attorney General William D. Mitchell, the Advisory Committee's chairman, ${ }^{129}$ that there was a serious risk that the profession would reject the major expansion of the discovery system the committee contemplated unless the rules clearly incorporated machinery for containing and punishing abuses. ${ }^{130}$ It was that apprehension that led Mitchell to endorse the idea that the new discovery rules provide that a party could petition a court to appoint a master to preside at a deposition and to make rulings about whether given questions had to be answered. ${ }^{131}$ While there was no recent precedent in the federal system for delegating such authority, ${ }^{132}$ the committee knew that Missouri and Wisconsin had experience with versions of this idea, ${ }^{133}$ and Mitchell hoped that authorizing the appointment of a master with the power to limit questioning would quiet the reportedly widespread fears that counsel would use depositions as vehicles for uncharted and unlimited fishing expeditions. ${ }^{134}$

Moved by Mitchell and Wickersham, the committee voted (in November 1935) to direct Sunderland to add a provision for the appointment of a master to the rule specifying the officers before whom depositions could be taken. ${ }^{135}$ Sunderland complied, but as the text and notes of his first draft indicate, he was not enthusiastic about this proposal. Under his initial version of the rule, a party who applied for appointment of a master would have to "show . . . special and unusual circumstances sufficient to satisfy the court that the deposition cannot be satisfactorily taken" before one of the officers otherwise used to record depositions. ${ }^{136}$ Sunderland's unhappiness with this whole notion was even more visible in the first draft of the note he proposed for this part of the deposition rules. With his citations omitted, the note read:

The taking of testimony by a master should be the exception rather than the rule. It is very expensive. Federal equity rules regarding the use of masters have been widely criticized on account of expense. Lane, in 35 Harvard Law Rev. 296-7, suggests that these rules "should be eliminated or radically changed."

It is questionable whether a master should exercise the power of excluding

129. Order of Appointment, supra note 115.

130. Proceedings for Feb. 22, 1936, supra note 123, at 727, 735.

131. Id. at 727.

132. Under Equity Rules 49 and 51 , examiners before whom depositions were taken had no authority to exclude evidence or to rule that a deponent need not answer a question. See Dobie, supra note 53, at 721 .

133. The note that Sunderland subsequently wrote for the rule that would have authorized delegating this power to masters cited George Ragland's monograph (supra, note 90) and acknowledged its discussion of the roles masters could play in depositions in state courts in Wisconsin and Missouri. Sunderland was quite familiar with Ragland's work; he wrote the foreword for Ragland's monograph and apparently supervised Ragland's research, which was conducted from the Law School of the University of Michigan where Sunderland was professor of legal research. See Edson R. Sunderland, Foreword to Ragland, supra note 90 , at iii-iv.

134. Proceedings for Feb. 22, 1936, supra note 123, at 727, 735.

135. Id. at 750.

136. Rule 30, Officers Before Whom Depositions May Be Taken. Letters Rogatory, subparagraph (d) and notes thereto (Tent. Draft II, unpublished, Jan. 13, 1936), Box 98, Clark Papers, supra note 113. 
evidence in the taking of depositions. In performing this duty he is not engaged in making findings or giving opinions but only in taking testimony.

Modern discovery and deposition procedure makes practically no use of officers having power to decide objections. ${ }^{137}$

Sunderland was not the only member of the committee who was uncomfortable with this proposal. There was considerable tension between the notion that a master should be empowered to limit questioning during depositions and the larger objective of expanding and opening up the discovery process. That tension surfaced when the committee debated Sunderland's draft in late February 1936. Surprisingly, it was Mitchell who initiated reconsideration of the proposal he had urged just three months earlier. The former Attorney General opened the discussion by suggesting a change that would work a compromise between those who favored expansive discovery opportunities and those who feared abuses. Mitchell's original proposal, captured in Sunderland's first draft, would have permitted the appointment of a master to preside at a deposition of any person, regardless of his or her relation to the parties. ${ }^{138}$ The compromise Mitchell suggested in the February meeting would permit courts to appoint a master only when the deposition was of an adverse party (or of an officer, employee, or agent of such a party). ${ }^{139}$

This suggestion sparked a spirited debate. Sunderland and Harvard law professor Edmund M. Morgan ${ }^{140}$ led an attack on the underpinnings of the concept itself. Sunderland began by exclaiming: "I do not see how this thing will work anyway. I do not find any authority for these examiners or masters ruling on testimony. The equity rule expressly provides that all evidence before an examiner or like officer, together with objections, shall be saved and returned into court." ${ }^{141}$ After being interrupted by Morgan's observation that "it would be very unfortunate to let a master rule on evidence," 142 Sunderland went on to insist that delegating such a power would be "contrary to the universal practice" and would represent "a serious retrogression" in the rules. ${ }^{143}$ Morgan added that giving masters the power to limit questioning "would be inviting appeals." 144

These objections temporarily pushed Mitchell into a retreat; he confessed to feeling that his original proposal, "which was made to quiet the fears of General Wickersham and others, probably was not a sound one." 145 That tentative concession, however, spurred protests from Robert G. Dodge of Boston and Warren Olney, Jr., of San Francisco. ${ }^{146}$ Dodge supported the

137. Id.

138. Id.

139. Proceedings for Feb. 22, 1936, supra note 123, at 727.

140. Order of Appointment, supra note 115.

141. Proceedings for Feb. 22, 1936, supra note 123, at 729.

142. Id.

143. Id. at $729-30$.

144. Id. at 730 .

145. Id.

146. Order of Appointment, supra note 115. 
general movement toward liberalizing discovery, but he insisted that powerful forces in his state did not share his view and that the committee would "have to cloak [the discovery system it was fashioning] in such a way as to make it popular in those parts of the country where they were totally unfamiliar with it."147

These exchanges opened the whole area for debate. The committee considered and rejected seriatim several alternative devices that might curb abuses. ${ }^{148}$ Under one proposal, for example, every objection to a question posed during a deposition would have been referred immediately to a judge. ${ }^{149}$ The committee discarded this idea on the ground that the procedure would interfere too much with the courts' other business and thus would defeat one of the primary purposes of taking testimony out of court. ${ }^{150}$ In the course of the ensuing consideration of other alternatives Mitchell rediscovered his earlier conviction that there would be "an outburst against this discovery business unless [the committee could] hedge it about with some appearance of safety against fishing expeditions." 1 1st Fortified by this renewed conviction, Mitchell led an abrupt rejection of a proposal by Sunderland that the rules include "a provision for a master on application, just to look well, but not . . . anything about giving the master power to exclude evidence." 152 Sunderland tried to argue that his proposal represented more than a cosmetic because the mere presence of a "highclass man" would restrain excesses. ${ }^{153}$ But Mitchell and Monte M. Lemann of New Orleans ${ }^{154}$ disposed of Sunderland's suggestion by persuading the committee that the presence of a neutral but powerless lawyer would do nothing for the process that was not already done by the presence of a notary. ${ }^{15 s}$ Lemann was particularly curt, arguing that since Sunderland's "high-class man" could only "sit there and look pleasant" the courts "might as well have a low-class man." 156

When additional efforts to fashion alternatives proved fruitless, the committee voted to endorse the compromise proposal with which Mitchell had opened the debate: Sunderland was to redraft the rule so that a master with the power to resolve disputes about the admissibility of evidence could be appointed (on motion, for good cause shown) only for a deposition of a party. ${ }^{157}$ This compromise provision appeared as paragraph (b) of Rule 32 of the Preliminary Draft of Rules of Civil Procedure ${ }^{1 s 8}$ that the committee published in May 1936 and circulated for comment.

147. Proceedings for Feb. 22, 1936, supra note 123, at 730-31.

148. Id. at 731-43.

149. Id. at 731-34.

150. Id. at 735 .

151. Id.

152. Id.

153. $I d$.

154. Order of Appointment, supra note 115.

155. Proceedings for Feb. 22, 1936, supra note 123, at 735.

156. Id.

157. Id. at 760-61.

158. Rule 32(b), Preliminary Draft, supra note 114 , at 60-61. 
While the committee was developing its first publicly expressed position about the use of masters in depositions, it also made parallel (and instructive) changes in the rules designed to guide conventional, trial-stage references. As I indicated above, the first draft of the rules about referencing did not mention pretrial discovery or any discovery rules. ${ }^{159}$ After the committee voted (in November 1935) to include the provision for appointing masters in the deposition rule, however, Dean Clark ${ }^{160}$ redrafted the general rule about references so that it would simultaneously acknowledge the additional role for masters in discovery and make it clear that the exceptional condition requirement was not to apply to the appointment of a master to supervise a deposition. Rule A12 of the tentative draft dated December 26, 1935, was entitled "Reference to Masters-Exceptional, Not Usual." The first sentence read:

Except as provided in Rule 30 (ref. to a master to take depositions), and except in matters of account, a reference to a master, which in these rules includes a referee, an auditor, or an examiner, shall be the exception, not the rule, and shall be made in jury cases only to simplify the issues when such are complicated, and in non-jury cases only upon a showing that some exceptional condition requires it. ${ }^{161}$

The second (and only other) sentence of the rule began with the words "When such a reference is made . . . ." and proceeded to describe the time frame in which the master should hold "a hearing" on the matter referred. ${ }^{162}$ The phrase "such a reference" and the allusion to a "hearing" suggest that the committee did not intend the provisions in this rule about trial-stage references to apply to the use of a master under the deposition rule.

There is additional evidence to support this inference. At a meeting in early February 1936, the committee reviewed the version of Rule A12 discussed in the preceding paragraph. During this review Sunderland argued in favor of deleting any allusion to the use of masters in depositions from the rules about trial-stage references. ${ }^{163}$ More significantly, he went on to urge the committee to put "a provision .. . into Rule 30(c) that the rules regarding references to masters do not apply to depositions." 164 The transcript of the committee's deliberations reflects no opposition to these views. Instead, it shows Dean Clark agreeing to strike the allusion to use of masters

159. See supra notes $117-18$ and accompanying text.

160. The Report of the Advisory Committee that accompanied the Proposed Rules, supra note 114, at vii, states:

The rules, other than those on depositions, discovery, and summary judgments, were drafted under the supervision of Charles E. Clark, the Reporter, on whose staff James William Moore, Joseph M. Friedman, and others have rendered, valuable service. Edson $R$. Sunderland supervised the draft on depositions, discovery, and summary judgments.

161. Rule A12 (Tent. Draft II, Dec. 26, 1935), Box 98, Clark Papers, supra note 113 (the tentative number of this rule, A12, was crossed out, and the number 54 inserted above it, in the draft in the Clark Papers) (emphasis added).

162. Id. (emphasis added).

163. Proceedings for Feb. 5, 1936, vol. 12, p. 1069, Box 95, Clark Papers, supra note 113.

164. Id. (emphasis added). 
in depositions from the rule about trial-stage references and asking Sunderland to "take care of it in the other rule." 165 Clark did as he promised. The next draft of the general rule about trial-stage references did not mention the use of masters in discovery. ${ }^{166}$ In fact, there was no allusion to pretrial discovery in any subsequent draft of any of the rules about conventional references.

While Clark was deleting the reference to depositions from the rule about delegating trial-stage duties to masters, Sunderland was redrafting the relevant portions of the discovery rules. His first draft (January 1935) appears to have been premised on the assumption that the constraints Equity Rule 59 imposed on trial-stage references would apply to use of masters in pretrial depositions. The text of both the proposed rule and note incorporated Rule 59's exceptional condition ${ }^{167}$ requirement. The text announced that a court could appoint a master to monitor a deposition only if the applicant could "show . . . special and unusual circumstances sufficient to satisfy the court that the deposition [could not] be taken" before one of the kinds of officers who routinely performed this function (e.g., a notary). ${ }^{168}$ And the first line of the note Sunderland initially proposed for this portion of the rule was an almost verbatim restatement of the key provision of the first sentence of Equity Rule 59. That rule had begun by declaring that "Save in matters of account, a reference to a master shall be the exception, not the rule." ${ }^{169}$ Sunderland's proposed note began: "The taking of testimony by a master should be the exception rather than the rule." 170

Sunderland redrafted this rule and note after he persuaded the committee (in February 1936) to drop the allusion to discovery from the rule about trial-stage references and to include a statement in the provision for depositions that "the rules regarding references to masters do not apply to depositions." "171 While Sunderland's next draft did not make this point as explicitly as he had made it during the February meeting, the revised text and note reflected none of the influence of Equity Rule 59 that had been so obvious in the first draft. ${ }^{172}$ Indeed, the revised versions of the rule and note seemed

165. Id. at 1069-70.

166. Rule A13, Reference to Master-Exceptional, Not Usual (Tent. Draft III, Mar. 1936), Box 98, Clark Papers, supra note 113.

167. 1912 Equity Rule 59, supra note 14, at 666.

168. Rule 30(d), supra note 136.

169. 1912 Equity Rule 59, supra note 14 , at 666 .

170. Note to paragraph (d), Rule 30, supra note 136.

171. See text accompanying supra notes 163-64.

172. The relevant rule was renumbered and rearranged in the March 1936 redraft. What had been Rule 30(d) appeared as Rule 33(b). What follows are the full texts of this paragraph, and the note to it, as Sunderland wrote them for the March 1936 draft:

Rule 33 ...

(b) 'Before a Master [in pencil] When notice is served for taking the deposition by oral examination of any party, or of an officer, director, agent or employee of any party, the court in which such action is pending may, on motion promptly made by such party on good cause shown, make an order directing that such deposition shall be taken before a standing master of the court or a special master appointed for that purpose, and authorizing such master to rule on the admission of evidence. The order shall fix the master's fees and they shall be advanced by the moving party. 
designed to stand wholly on their own. They set forth their own procedural guidelines and made no allusions to the rules about trial-stage references. Most significantly, Sunderland had deleted all the language that had suggested that the requirements of Equity Rule 59 would apply to the use of masters to supervise depositions. The new note said nothing about such appointments being the exception rather than the rule, and the new text would permit an appointment merely "on good cause shown." "Th3 The requirement that an applicant show "special and unusual circumstances" was gone.

The Advisory Committee approved Sunderland's revisions and incorporated his redrafted text as paragraph (b) of Rule 32 in the Preliminary Draft of Rules of Civil Procedure that the Committee published and circulated for comment in May 1936. ${ }^{174}$ Before describing the fate of this provision I should emphasize an important point. The history of the Advisory Committee's deliberations and the evolution of its drafts of the rules make it quite clear that by the time the committee publicly recommended limited use of masters in connection with pretrial discovery the Committee had concluded: (1) that separate provisions should be made for use of masters in depositions and in conventional trial-stage references and (2) that the preconditions and procedural requirements applicable to the latter should not apply to the former. In other words, by the time the committee circulated its first published draft it had concluded that the rules about trial-stage references should not.provide for use of masters in the discovery stage. This conclusion is especially important because the rules about trial-stage references remained essentially unchanged through subsequent drafts ${ }^{175}$ and in the version of the Federal Rules of Civil Procedure that the Supreme Court and Congress finally adopted in 1937 and 1938. ${ }^{176}$

The provision for appointing masters to monitor depositions suffered a radically different fate. Its appearance in the committee's first published draft reportedly triggered "considerable objection by the profession." 177 Unfortunately, the papers of the Advisory Committee that Dean Clark preserved do not detail these objections or record the committee's consideration of them. There is, however, one published description of the adverse reaction. Edward H. Hammond, a Justice Department lawyer who served on the staff of the Advisory Committee, ${ }^{178}$ published an article in mid-1937 explaining changes in the rules the committee made after it digested the criticisms and suggestions provoked by the first published draft. ${ }^{179}$ Accord-

(b) The provision for reference to a master is for the purpose of protecting parties from oppression in cases where there is reason to believe that the examination is likely to include matters not properly subject to discovery. It is introduced as a safeguard on account of the unlimited right of discovery given by Rule 32.

Rule 33(b) (Tent. Draft III, Mar. 1936), Box 98, Clark Papers, supra note 113.

173. Id.

174. Rule 32(b), Preliminary Draft, supra note 114.

175. In addition to the Proposed Rules (April 1937) and Final Report (Nov. 1937), supra note 114, see Hammond, supre note 25, at 633 .

176. Fed. R. Civ. P. 53, originally published in 308 U.S. 645, 727-31 (1939).

177. Hammond, supra note 25 , at 632 .

178. Report of the Advisory Committee, in Proposed Rules, supra note 114, at vii.

179. Hammond, supra note 25 . 
ing to Hammond, there were several different grounds upon which lawyers had objected to the provision for the appointment of masters to supervise depositions of parties. The aspect of the proposal that provoked the most concern was the same aspect that had so troubled Sunderland and Morgan: "the provision giving [a master] the power to rule on evidence." ${ }^{180} \mathrm{Ham}$ mond reported that the specter of masters with that kind of power had triggered substantial apprehension that these appointees might in fact "hamper the desired freedom of discovery." "181 Lawyers also had expressed fears that the added expense of masters' fees might "act as a deterrent to the use of discovery and would give an unfair advantage to those more able to pay them." 182

Not all of the reaction to Rule 32(b) of the preliminary draft was negative. Concern about potential abuses of the new discovery machinery inspired some support for this provision ${ }^{183}$ and moved one commentator to suggest that the rules authorize an even larger role for masters in the discovery process. In an article evaluating the discovery rules as proposed in the first published draft, Martin Conboy, a New York lawyer, argued that the rules should establish some means through which the judiciary could rule on the propriety of deposition questions before a witness or party had to respond. ${ }^{184}$ Appreciating that requiring judges to rule on all disputed deposition questions might impose serious strains on courts' schedules and resources, Conboy made the following tentative suggestions:

Perhaps the judge should have the power to appoint a master on his own motion, if either objector or interrogator should be unduly aggressive. Power might even be conferred upon the judge to decide who should advance the expense of the master in such cases. It may be advisable to accord counsel at any stage of the examination the privilege of moving for the appointment of a master to pass upon all further questions. Perhaps only experience can demonstrate the necessary safeguards without imposing an undue burden upon our Federal judges, but the right to a judicial determination seems necessary where the production, inspection and copying of documents and papers is involved. ${ }^{\text {iss }}$

Apparently views like Conboy's were in the minority. When the Advisory Committee reconsidered the matter in light of public reaction to the Preliminary Draft, the sentiments initially expressed by Sunderland and Morgan prevailed. In October 1936 the committee decided to withdraw para-

180. Id. at 632.

181. Id. During the Advisory Committee's debate over this proposal, Morgan had declared:

I want the situation so that the answer of the witness is somehow preserved, so that the deposition will not go for naught on the particular thing. If it is a hard fought case before a master, it will be an exceptional master who does not make errors in his rulings on evidence.

Proceedings for Feb. 22, 1936, supra note 123, at 735.

182. Hammond, supra note 25 , at 632 .

183. See, e.g., Werner Ilsen, The Preliminary Draft of the Federal Rules of Civil Procedure, 11 St. John's L. Rev. 212, 233-34 (1937).

184. Martin Conboy, Depositions, Discovery and Summary Judgments, 22 A.B.A.J. 881, 883-84 (1936).

185. Id. 
graph (b) of Rule 32 and, with it, the idea that the rules should authorize the appointment of masters in connection with the deposition process. ${ }^{186}$

Simultaneously, the committee decided that the best way to cope with potential abuses of the deposition machinery was to directly involve the judges themselves in the peace-keeping process ${ }^{187}$ and toward that end to streamline litigants' access to the courts during the pretrial period. Thus, instead of empowering courts to appoint masters to deal with problem depositions, the final draft of the rules left responsibility for policing deposition behavior solely in the hands of the judges. Paragraphs (b) and (d) of the final version of Rule 30 included a long list of kinds of orders courts could enter in order to protect witnesses' rights and preserve the civility of deposition proceedings, ${ }^{188}$ but these paragraphs did not even hint at the possibility of using masters for such purposes. In the end then, the Advisory Committee embraced a notion that played a central role in the 1912 reforms of the Federal Equity Rules: the notion that the discovery system would work best when there were no quasi-judicial officers interposed between the litigants and the courts. ${ }^{189}$

The significance of the deliberations and decisions described in the preceding paragraphs seems clear: by the time it sent its final product to the Supreme Court, the Advisory Committee had concluded that the Federal Rules of Civil Procedure should not authorize courts to appoint masters in connection with pretrial depositions. The records of the committee's work

186. Proceedings for Oct. 22-27, 1936, Folder 15, Box 96, at 58-61, Clark Papers, supra note 113. Unfortunately, these parts of the minutes of the committee's meetings do not record substantive discussion and therefore do not expose the specific motivation that led individual members to vote for this important change.

187. Cf. Hammond, supra note 25, at 632, and Hubert Dee Johnson, Depositions, Discovery, and Summary Judgments Under the Proposed Uniform Federal Rules, 16 Tex. L. Rev. 191, 196 (1938).

188. Rule 30, Rules of Civil Procedure for the District Courts of the United States, 308 U.S. 645, 700-704 (1939).

189. In 1938, during a symposium held for the purpose of explaining the new rules, Edson $R$. Sunderland pointed out that under what was then $\S 301$ of New York's Civil Practice Act a deposition could be "taken before an attorney or counsellor-at-law." He then declared, without elaboration: "That would not be permissible under the federal rules." See statement of Edson R. Sunderland in Edward H. Hammond, ed., Federal Rules of Civil Procedure, Proceedings of the Institute at Washington, D.C., and of the Symposium at New York City, Oct. 17-19, 1938, at 257 (Chicago: American Bar Association, 1939).

It appears that when attorneys presided at depositions under this New York statute they had no greater authority than a notary and were not empowered to rule on the propriety of questions or to compel answers. In 1962 the Civil Practice Act was replaced by the New York Civil Practice Law and Rules, Rule 3113 of which replaced $\S 301$ of the Civil Practice Act. Rule 3113 dropped attorneys and counselors at law from the list of persons before whom depositions could be taken. See Book 7B, Civil Practice Law and Rules, Consolidated Laws of N.Y., Annotated (Edward Thompson Co. 1963) Rule 3113 and accompanying Practice Commentary by Caesar L. Pitassy \& William J. Ryan, at 230-32. See also Sackren v. Smirnow, 63 N.Y.S.2d 224, 225 (Kings County Sup. Ct. 1946).

There is post-1938 precedent in New York courts for appointing a "Referee" to "preside at all depositions, determine the order and extent of participation therein by counsel . . . and, subject to the order of the court, rule in the first instance upon all objections and motions relating to depositions." According to the New York court that approved delegating this authority to a referee: "This procedure would avoid the duplication, confusion and harassment necessarily involved in the taking of the numerous and lengthy depositions contemplated by counsel under the unusual conditions of joint examinations conducted by [several] counsel." Armstrong v. Doyle, 20 Misc.2d 1091, 1092-93 (N.Y. County Sup. Ct. 1959). 
show that the absence from Rule 53 (and from the discovery rules) of even an allusion to the possibility of delegating pretrial tasks to masters was not the product of oversight or careless drafting; rather, it reflected a fully selfconscious rejection of the idea that the Federal Rules should sanction the use of masters in connection with discovery proceedings.

There is one additional but less direct source of support for this view. Some members of the Advisory Committee, including former Attorney Generals Mitchell and Wickersham, believed that pretrial practice in American courts could be made much more efficient if it could incorporate some version of the English procedure known as "Summons for Directions." 190 Under the English system, standing masters summoned counsel to a pretrial conference shortly after the pleadings were closed. At this conference, which was mandatory in all cases, the master's objective was to help the parties streamline case development, focus their dispute, and organize the matter for trial. Toward these ends, the master would review the pleadings with counsel, help identify issues that could be eliminated by stipulations or admissions, help plan discovery and document exchanges, and make preliminary decisions about modes of proving particular facts (e.g., whether they would be tried to a jury or a chancellor). ${ }^{191}$

For our purposes, the most significant aspect of the Advisory Committee's work with this British idea is the committee's conclusion that it would be infeasible and improper to attempt to establish such a system through the rules of procedure. ${ }^{192}$ England's standing masters were (and remain) public employees, paid from public funds. ${ }^{193}$ The federal court system, as structured and funded by Congress in the 1930s, included no officers comparable to these English masters. ${ }^{194}$ The Advisory Committee knew that it could not

190. See Proceedings for Nov. 4, 1935, supra note 126, at 252, showing Wickersham and Robert G. Dodge supporting efforts to copy the English use of standing masters, but Mitchell warning that Congress was not likely to appropriate funds to pay such officers. The Advisory Committee received at least one statement of opposition to this idea. See Suggestions of Local Committees, Preliminary and Informal Report of Frederic R. Kellog, Chairman, S.D. New York, Commenting on Rule 38 of Tentative Draft I, Box 97, Clark Papers, supra note 113. Kellog wrote:

Tentatively, I feel [the English system of Summons for Directions] is not applicable to our American conditions or our American practice. It would, to my personal knowlege, have worked injustice in certain litigation with which I have been connected, the mechanism of which could not possibly have adequately been determined within a few days after joinder of issue, even by a trained master.

And we have no trained masters.

Possibly the feeling which I entertain is more applicable in cases arising in the sparsely populated regions of certain of our middle western and other states.

191. See statement of Edson R. Sunderland in American Bar Association, supra note 12, at 295-98; see also William C. Mitchell, Some of the Problems Confronting the Advisory Committee in Recent Months-Commencement of Actions-Effect of Findings of Fact in Cases Tried by Court Instead of Jury, Etc., 23 A.B.A. J. 966, 967-70 (1937); Testimony by Edgar B. Tolman, in Rules Hearings, supra note 25, at 106-7; and statement of Challon B. Ellis, id. at 147-50.

192. Cf. Mitchell, supra note 191, at 970; Proceedings of Nov. 4, supra note 126, at 252.

193. Mitchell, supra note 191, at 970; also see John Biggs, Jr., A System of Masters, 23 F.R.D. 563 (1958); Joseph C. Zavatt, The Use of Masters in Aid of the Court in Interlocutory Proceedings, 22 F.R.D. 283 (1958). For a comprehensive description of the roles masters play in modern English procedure, see generally Silberman, Part I, supra note 1.

194. United States commissioners were the only even remotely comparable officers, but they rarely played significant roles in civil adjudication. See McCabe, supra note 1, at 345-47. 
submit rules premised on the assumption that Congress would agree to add a new category of officer for all federal courts and then appropriate the funds to support such a position. ${ }^{195}$ Given that limitation (made more real by the pressure the Depression put on federal spending), the only alternative would have been to draft a rule that would empower the courts to compel the parties to pay for a master's pretrial work. Apparently the committee never even seriously flirted with that possibility. As Mitchell explained in an article in the American Bar Association Journal in 1937, "it would be out of line with American ideas to compel the litigants to pay the compensation of a master conducting pre-trial proceedings." 196

Constrained by these assumptions, the committee decided that the rules should go no further than to authorize the district judges themselves to conduct pretrial proceedings comparable to those conducted by standing masters in England. ${ }^{197}$ Thus Rule 16 of the draft endorsed by the Supreme Court and Congress contemplated district judges presiding at pretrial conferences and performing the kinds of case preparation functions standing masters performed in England. ${ }^{198}$ There was no suggestion in that rule that the courts could delegate responsibility for such pretrial proceedings to special masters and compel the litigants to foot the bill. The only role for a master that Rule 16 acknowledged was a conventional reference of issues "for findings to be used as evidence when the trial is to be by jury." 199

In sum, all the evidence I have uncovered about the history of the drafting of the provisions in the Federal Rules of Civil Procedure for pretrial proceedings, discovery, and references to masters supports the same conclusion: the Advisory Committee did not intend the rules to authorize federal judges to delegate responsibility for pretrial discovery matters to special masters.

\section{B. Inferences from the Language and Structure of the Rules}

These conclusions from historical evidence are reinforced by the content of Rule 53. Commentators who have studied Rule 53 have cautiously suggested something that the courts either have not perceived or have chosen to ignore: the text and structure of the rule invite the inference that the only uses of masters it authorizes and guides are the conventional trial-stage references that have long been a part of federal practice. ${ }^{200}$ For example, in his valuable essay about using masters at the remedial stage of institutional reform litigation, Vincent Nathan points out that "the entire thrust of Rule 53

195. Mitchell, supra note 191, at 970. Also see Proceedings of Nov. 4, supra note 126, at 252.

196. Mitchell, supra note 191 , at 970.

197. After the Advisory Committee concluded that it could not submit rules authorizing judges to delegate pretrial duties to standing masters, Mitchell urged Congress to enact legislation creating the office of standing master. See Mitchell, supra note 191, at 970; testimony of Edgar B. Tolman (Secretary of the Advisory Committee), Rules Hearings, supra note 25, at 106-7.

198. Fed. R. Civ. P. 16.

199. Id. See also the Advisory Committee's original Note to Rule 16, reproduced in 12 Wright \& Miller, supra note 25, at 396 appendix C.

200. Silberman, Part II, supra note 1, at 1322-24. 
appears to be toward the use of a master as a fact-finder in advance of the court's remedial decree or as an expert to recommend the amount of damages or other remedial relief after a finding of liability." "201 Two decades earlier Judge Kaufman observed that the rule appeared to "have been written in contemplation of reference of issues of fact only."202 The judge went on to suggest that authority to delegate tasks to special masters during the discovery stage would have to be "found outside the pale of the rule."203 Other comentators also have raised questions about the applicability of Rule 53, or at least of all of its limiting provisions, to pretrial appointments. ${ }^{204}$

The text of the rule makes such reservations understandable. ${ }^{205}$ Read as a whole, the rule clearly is oriented toward conventional references at the trial stage. It empowers masters to hold hearings, to compel testimony and the production of documents, and to prescribe the forms in which accounts shall be stated and the manner in which they shall be proved. ${ }^{206}$ It sets forth rules about when and how proceedings before the master shall be conducted, ${ }^{207}$ how he is to make his report, and how the court is to treat his findings of fact and conclusions of law. ${ }^{208}$

The general impression created by the structure of the rule, that it was drafted in contemplation only of trial-stage references, is reinforced by several of its specific provisions. Paragraph (b), which is the only part of the rule that alludes to the circumstances under which appointments can be made, divides the universe of references into two categories: those in actions to be tried by a jury and those in actions to be tried without a jury. ${ }^{209}$ In

201. Vincent M. Nathan, The Use of Masters in Institutional Reform Litigation, 10 U. Tol. L. Rev. 419,428 (1979). Nathan's article focuses on using masters to monitor or implement equitable decrees. He suggests that such uses of masters may fall outside the reach of Rule 53 and its exceptional condition requirement. Id. at $423-33$. He does not squarely address our question about whether the rule serves as authority to delegate tasks to masters during the pretrial discovery period.

202. Kaufman, supra note 10, at 455 n.18. Unfortunately, Judge Kaufman did not detail the reasoning behind his views on these matters. And despite his belief that Rule 53 was not designed to authorize references of discovery matters, Kaufman argued that one of the policies reflected in Rule 53(b), that references should be the exception and not the rule, should apply to all appointments of masters, regardless of the task assigned or the stage of litigation involved. Id. at $455 \mathrm{n} .18,462,464-65$.

203. Id. at 462,465 .

204. See, e.g., Special Project, The Remedial Process in Institutional Reform Litigation, 78 Colum. L. Rev. 784, 831 (1978); Silberman, Part II, supra note 1, at 1342-43; Comment, Developments, supra note 10, at 1004; Comment, supra note 1, 798 n.130, 800 \& n.141 (focusing in both places on whether Rule 53's requirements apply to magistrates to whom a judge delegates tasks that fall outside the conventional trial-stage reference).

205. The current version of Rule 53 is set forth in full in the appendix to this article. The Advisory Committee's proposed amendments to this Rule, none of which would answer the basic questions addressed in the text, can be found in the following places: Advisory Committee on Civil Rules, Preliminary Draft of Proposed Amendments to the Federal Rules of Civil Procedure, Note to Rule 53 (June 1981), published in pamphlet form and bound with the advance sheet versions of $101 \mathrm{~S}$. Ct. (July 15, 1981); also published at 90 F.R.D. 451 (1981). After making modest changes in these proposed amendments, the Advisory Committee forwarded them to the Judicial Conference, which, in September 1982, approved the amendments and forwarded them to the United States Supreme Court for consideration.

206. Fed. R. Civ. P. 53(c), (d).

207. Id.

208. Fed. R. Civ. P. 53(e).

209. Fed. R. Civ. P. 53(b). 
other words, the only criterion this section uses to categorize references is the character of the trier of fact (judge or jury). The fact that this important paragraph relies exclusively on this one criterion to distinguish types of references strongly suggests that the drafters of Rule 53 expected the appointments under it to be made in conjunction with trial.

The same inference is supported by the precondition paragraph (b) imposes on references in jury cases: in such matters, a court is permitted to appoint a master "only when the issues are complicated." 210 Since a jury has no responsibility for pretrial proceedings, and since the only "issues" a jury decides are those remaining in the case at the time of trial, it seems obvious that the assumption underlying this "complexity" requirement is that an expert master might be used at the trial stage to help jurors unravel unusually difficult issues or evidence.

The same assumption informs the limitations that paragraph (e) imposes on a master's report in a jury action: in such cases, a master may not "report the evidence," but his or her "findings" on the "issues submitted to [him] are admissible as evidence . . . and may be read to the jury."211 Although less obviously, paragraph (e)'s command that in nonjury actions the court must "accept the master's findings of fact unless clearly erroneous"212 also seems to be premised on the assumption that the master will be used in connection with trial.

While Rule 53 does not purport to identify all the tasks it authorizes courts to assign to masters, its failure even to allude to discovery activity reinforces the impression that its drafters did not expect judges to rely on this rule as authority to refer discovery matters. The word "discovery" is nowhere to be found in Rule 53. Nor does the text of the rule mention any of the means of discovery provided for in Rules 26 through 36. It also seems significant that the only allusion to Rule 37 sanctions is in connection with unexcused failures by witnesses to appear at or testify in proceedings before masters. ${ }^{213}$ No part of either Rule 53 or Rule 37 suggests that masters should be involved in enforcing the parties' pretrial discovery obligations.

By contrast, the kinds of roles, functions, and powers Rule 53 does mention are closely associated with the trial stage of civil adjudication. For example, paragraph (a) lists the titles of judicial officers that the word "master," as used in Rule 53, "includes." Those named are "a referee, an auditor, an examiner, a commissioner, and an assessor." "214 From the time this

210. Id. (emphasis added).

211. Fed. R. Civ, P. 53(e)(3).

212. Fed. R. Civ. P. 53(e)(2).

213. Fed. R. Civ. P. 53(d)(2).

214. Fed. R. Civ. P. 53(a). As originally adopted, the part of paragraph (a) quoted in the text referred only to "a referee, an auditor, and an examiner." 308 U.S. 728 (1938). The words "commissioner" and "assessor" were added to the list in 1966 as part of revisions "designed to preserve the admiralty practice whereby difficult computations are referred to a commissioner or assessor, especially after an interlocutory judgment determining liability." See Advisory Committee's note to 1966 amendment of Rule 53 , reproduced in 12 Wright \& Miller, supra note 25 , at 493 appendix C. 
rule was drafted, judicial officers with these titles have been associated with the fact-finding process (including assessing damages), not with pretrial discovery.

It also seems significant that under paragraph (c) a judge can empower a master to "require the production before him of evidence," "rule upon the admissibility of evidence," put witnesses and parties under oath, and then examine them. ${ }^{215}$ As I explained in the preceding section, Rule 53 was intended to perpetuate practices developed under the Federal Equity Rules; it was not designed to radically alter the adversary system. Yet giving a judicial officer power to determine what evidence should be adduced, to decide who should testify, and then to conduct the examinations himself or herself, obviously would represent a substantial threat to basic premises of the adjudicatory system if the officer could use these powers more than occasionally and outside of narrowly circumscribed situations. Thus it is most likely that when the drafters of Rule 53 authorized the federal judiciary to confer such extraordinary power on a master they assumed that the courts would do so only under the circumstances recognized as appropriate in contemporary practice (i.e., only when assistance was needed to ascertain unusually elusive facts or to penetrate particularly dense or esoteric data about damages). There is absolutely no reason to believe that the drafters of Rule 53 foresaw masters wielding the quasi-inquisitorial powers listed in paragraph (c) during pretrial discovery proceedings. The discovery system as contemplated in the Federal Rules of Civil Procedure was to be largely self-executing, and the primary locus of responsibility for it was to rest with counsel. ${ }^{216}$ Thus it would have been completely inconsistent with common expectations about the proper role of the judiciary during pretrial to provide for special masters who could move into the discovery arena with the power to specify which documents were to be produced and to call and examine witnesses. A master so endowed would have displaced the parties. No one expected that.

The structure of the rules suggests additional reasons for believing that the drafters expected special masters appointed under Rule 53 to function at the trial stage, not during pretrial discovery. One such reason is based on the location of Rule 53: from the beginning, it has been in section VI, which is entitled "Trials." 217 None of the rules in that section deals with pretrial discovery, and perhaps more significant, none of the rules in the separate section devoted to "Depositions and Discovery"218 even hints at the possibility that special masters might be involved in the discovery process.

Outside of Rule 53, only two rules mention the word master. One is Rule 52 , which also is in the section devoted to trials and which deals with "Find-

215. Fed. R. Civ. P. 53(c).

216. See Sherman L. Cohn, Federal Discovery: A Survey of Local Rules and Practices in View of Proposed Changes to the Federal Rules, 63 Minn. L. Rev. 253-54 (1979); Maurice Rosenberg \& Warren R. King, Curbing Discovery Abuse in Civil Litigation: Enough Is Enough, 1981 B.Y.U. L. Rev. $579,581$.

217. Fed. R. Civ. P. Section VI, "Trials."

218. Fed. R. Civ. P., Section V, "Depositions and Discovery," embraces Rules 26 through 37. 
ings by the Court." "219 The sole allusion to a master in this rule is in a sentence that declares: "The findings of a master, to the extent that the court adopts them, shall be considered as the findings of the court." ${ }^{220}$ Rule 16, which is located in the section devoted to "Pleadings and Motions," tains the other allusion to a master. Rule 16 includes a nonexhaustive list of subjects that court and counsel may consider at a pretrial conference. One of these subjects is described in these words: "The advisability of a preliminary reference of issues to a master for findings to be used as evidence when the trial is to be by jury." 222 Just as in Rule 52, this allusion to a master obviously contemplates service in connection with trial. ${ }^{223}$

In sum, a careful examination of the text and structure of the rules produces no support for the view that Rule 53 was intended to authorize judges to delegate duties to special masters during the discovery stage of civil actions.

\section{INHERENT Power to ApPoINT MASTERS}

If the Federal Rules of Civil Procedure do not empower federal courts to refer discovery tasks to special masters, is there some other source of authority for such appointments when litigants do not freely consent to them? While the matter is not completely free from doubt, the answer appears to be yes.

There is a well-established tradition in which federal courts have insisted that they are endowed with certain "inherent power." 224

The question we confront at this juncture is: does the concept of inherent power extend far enough to permit federal courts to delegate pretrial discovery tasks to special masters? 225

219. Fed. R. Civ. P. 52.

220. Fed. R. Civ. P. 52(a).

221. Fed. R. Civ. P. 16 is captioned "Pre-Trial Procedure; Formulating Issues." This rule authorizes courts to convene pretrial conferences. It is located in Section III, "Pleadings and Motions."

222. Fed. R. Civ. P. 16 (emphasis added).

223. The Advisory Committee's note to the original version of Rule 16 suggests that the committee expected masters to be used under this rule in the same ways, and under the same guidelines, as set forth in Rule 53. The original note states: "In connection with clause (5) [the clause alluding to possible use of masters] of this rule, see Rules 53(b) (Masters; Reference) and 53(e)(3) (Master's Report: In Jury Actions)." See 12 Wright \& Miller, supra note 25 , at 396 appendix C.

For an early example of the kind of use of a master contemplated in the original version of Rule 16 see Newcomb v. Universal Match Corp., 25 F. Supp. 169 (E.D.N.Y. 1938).

224. Ex parte Peterson, 253 U.S. 300, 312 (1920); Hanna v. Plumer, 380 U.S. 460, 472-73, quoting Lumbermen's Mut. Casualty Co. v. Wright, 322 F.2d 759, 764 (5th Cir. 1963); see also Ruiz v. Estelle, 679 F.2d 1115, 1159-63 (5th Cir. 1982).

225. In a law review article, Judge Irving $R$. Kaufman has answered this question, without qualification, in the affirmative. Kaufman, supra note 10, at 462-63, 465. Unfortunately, he did not demonstrate how the authorities he cites support his conclusion. I undertake that task later in this section of the text.

Another commentator, Vincent $M$. Nathan, has argued that at least in some situations federal courts have inherent authority to appoint masters. Nathan believes that Rule 53(b)'s requirements should not be strictly applied when, after a finding of liability in institutional reform litigation, a court uses a master to help fashion or implement a remedial decree. Nathan, supra note 201, at 423-32.

Some admittedly indirect support for the view that federal trial courts have inherent power to delegate discovery tasks to special masters derives from the fact that when exercising its original jurisdiction the Supreme Court seems to have relied on its inherent authority when appointing masters to take evidence 
Well before the Federal Rules of Civil Procedure took effect, there were federal courts that relied on inherent power when they appointed masters over the objections of litigants. While none of the masters appointed in these early cases was assigned tasks in pretrial discovery, ${ }^{226}$ the language in the opinions seems sufficiently broad to justify the inference that the courts invoking this power would have deemed it a sufficient basis for delegating discovery matters.

Ex parte Peterson, ${ }^{227}$ written by Justice Brandeis in 1920, is the seminal opinion in this area. Virtually every federal court that has since insisted that it has inherent power to appoint a master, regardless of the nature of the tasks referred (conventional trial-stage matters ${ }^{228}$ or special pretrial tasks ${ }^{229}$ ), has relied on Peterson and its progeny.

Peterson was an action at law that involved disputes about some 700 different items of account. ${ }^{230}$ At the trial court level, Judge Augustus N. Hand had decided to order an "auditor" to separate the matters in dispute from those upon which the parties were in agreement and then to take evidence and offer tentative opinions about who should prevail in the claims that remained unresolved. ${ }^{231}$ Hand's order made it clear that the auditor's role was not to make final determinations of disputed facts; rather, he was to prepare a nonbinding report to aid the court and the jury in organizing and digesting the case. ${ }^{232}$

When Brandeis confronted the issue of whether a federal court in a law action had authority to enter such an order he began by acknowledging that

and recommend findings of fact and conclusions of law. While the Court has not explicitly acknowledged a reliance on inherent power in this context, its orders of reference have cited no statutory authorization for this procedure. See, e.g., Nebraska v. Iowa, 379 U.S. 996 (1965), and Mississippi v. Louisiana, 346 U.S. 862 (1953). In United States v. Raddatz, 447 U.S. 667, 683 n.11 (1980), the Court described its use of special masters in the following passage:

In exercising our original jurisdiction under Art. III, we appoint special masters who may be either Art. III
judges or members of the Bar; the role of the master is, for these purposes, analogous to that of a magistrate.
The master is generally charged to "take such evidence as may be . . necessary," Nebraska v. Iowa, 379 U.S.
996 (1965), and to "find the facts specially and state separately his conclusions of law thereon." Mississippi v.
Louisiana, 346 U.S. 862 (1953). In original cases, as under the Federal Magistrates Act, the master's recommen-
dations are advisory only, yet this Court regularly acts on the basis of the master's report and exceptions thereto.

Similarly, the Oklahoma Supreme Court has held that when it exercises exclusive original jurisdiction it has "inherent power to appoint a referee with authority to hear cases . . . and to report the evidence with his findings of fact and conclusions of law." See R. Dale Vliet, The Inherent Power of Oklahoma Courts and Judges, 6 Okla. L. Rev. 257, 270 (1953). In Ruiz v. Estelle,679 F.2d 1115, 1159-63 (5th Cir. 1982), the court suggested that "inherent power" was a sufficient premise for appointing a special master to help implement an equitable decree (after conclusion of the liability phase).

226. As I already have indicated supra at pp. 156-60, there wasn't a great deal of "discovery" in federal courts in the nineteenth and early twentieth century.

227. 253 U.S. 300 (1920).

228. See Irving Trust Co. v. Trust Co., 75 F.2d 280, 282 (2d Cir. 1935); Veneri v. Draper, 22 F.2d 33, 35 (4th Cir. 1927); cf. Westchester Fire Ins. Co. v. Bringle, 86 F.2d 262, 263 (6th Cir. 1936) (dictum against backdrop of litigants' consent to the reference); Connecticut Importing Co. v. Frankfort Distilleries, 42 F. Supp. 225, 227 (D. Conn. 1940).

229. First Iowa Hydro Elec. Coop. v. Iowa-Illinois Gas \& Elec. Co., 245 F.2d 613, 627 (8th Cir.), cert. denied, 355 U.S. 871 (1957); Schwimmer v. United States, 232 F.2d 855 (8th Cir. 1956).

230. 253 U.S. at $304,306$.

231. Id. at 304-7.

232. Id. at 307. 
the "office of auditor with functions and powers like those here in question was apparently invented in Massachusetts" and that there was no "act of Congress" that "specifically authorized the adoption of [this] practice in the federal courts." ${ }^{233}$ Given the absence of statutory authorization, the "question," as Brandeis framed it, was "whether the [district] court possesses the inherent power to supply itself with this instrument for the administration of justice when deemed by it essential." 234

The subsequent influence of Brandeis' unhesitating answer is attributable in part to its clarity and vigor. He wrote:

Courts have (at least in the absence of legislation to the contrary) inherent power to provide themselves with appropriate instruments required for the performance of their duties. Compare Stockbridge Iron Co. v. Cone Iron Works, 102 Massachusetts, 80, 87-90. This power includes authority to appoint persons unconnected with the court to aid judges in the performance of specific judicial duties, as they may arise in the progress of a cause. From the commencement of our Government, it has been exercised by the federal courts, when sitting in equity, by appointing, either with or without the consent of the parties, special masters, auditors, examiners and commissioners. ${ }^{235}$

After describing some of the functions masters in equity had performed and after defending Judge Hand's conclusion that both he and the jury needed an expert's assistance, Brandeis declared that "no reason exists why a compulsory reference to an auditor to simplify and clarify the issues and to make tentative findings may not be made at law, when occasion arises, as freely as compulsory references to special masters are made in equity. . . . The inherent power of a federal court to invoke such aid is the same whether the court sits in equity or at law." 236

After Peterson and before 1938 there was no reason to doubt that federal courts had inherent power to order at least conventional, trial-stage references. The promulgation of the Federal Rules of Civil Procedure in 1938, however, was an unprecedented event that dramatically changed the procedural landscape. Did the new rules displace all the sources of authority on which the federal courts previously had drawn in fashioning procedural devices? The new rules displaced the Equity Rules $^{237}$ and clearly were designed

233. Id. at 309.

234. Id. at 312 .

235. Id. at 312-13.

236. Id. at 314.

237. See Letter of Submittal, Chief Justice Charles E. Hughes to Attorney General Homer Cummings, Dec. 20, 1937, published as a preface to the Rules of Civil Procedure for the District Courts of the United States, 308 U.S. 645, 649 (1939). Also see Hammond, supra note 386, at 182, where Robert G. Dodge, a member of the Advisory Committee, commented: 
to establish an integrated, nationally uniform system that would satisfy most of the procedural needs of federal trial courts. ${ }^{238}$

But did the notion that federal courts have inherent power in procedural matters survive the adoption of the Federal Rules of Civil Procedure, and, if so, can that power serve as a sufficient source of authority for assigning discovery tasks in large cases to special masters? The Supreme Court apparently has answered the first of these questions in the affirmative. I say apparently because the key sentence appears in a context that is at first blush confusing. In Hanna v. Plumer, ${ }^{239}$ the Court confronted a direct conflict between Rule 4(d)(1) of the Federal Rules of Civil Procedure and a Massachusetts statute prescribing a method for service of process in actions by creditors against decedents' estates. Because subject matter jurisdiction was based on diversity of citizenship, defendant had argued that under Erie Railroad Co. $v$. Tompkins, ${ }^{240}$ the state's service requirements had to be satisfied. ${ }^{241}$ Speaking for the Court, Chief Justice Warren rejected this view in an opinion he obviously designed to serve the larger purpose of erecting a doctrinal barrier that would discourage subsequent challenges to the constitutionality of applying the Federal Rules of Civil Procedure in this kind of situation. Thus the core of the Chief Justice's opinion consisted of a vigorous defense of Congress' power to adopt the rules. ${ }^{242}$

It was in the middle of this aggressive statement about the reach of the federal government's rule-making power and about the legitimacy of the Federal Rules that the Court endorsed the notion that federal trial courts retain inherent power in matters of procedure even after 1938. The Court explicitly embraced a passage written in a similar context by Judge Wisdom of the Court of Appeals for the Fifth Circuit:

"One of the shaping purposes of the Federal Rules is to bring about uniformity in the federal courts by getting away from local rules. This is especially true of matters which relate to the administration of legal proceedings, an area in which federal courts have traditionally exerted strong inherent power, completely aside from the powers Congress expressly conferred in the Rules. The purpose of the Erie doctrine, even as extended in York and Ragan, was never to bottle up federal courts with 'outcome-determinative' and 'integral-relations' stoppers-when there are 'affirmative countervailing [federal] considerations' and when there is a Congressional mandate (the Rules) supported by constitutional authority." ${ }^{243}$ [emphasis added]

On first reading, this passage might seem to be internally inconsistent. How could the Court praise the goal of national uniformity and criticize the influence of local rules at the same time it acknowledged that the district 
courts retain an independent "inherent power" in "matters which relate to the administration of legal proceedings"?

The key to the answer lies in the meaning of the phrase "local rules" as here used. The "local rules" to which the Court alluded in this passage were not those formulated by federal district courts but were the rules from state authorities that some federal trial courts, before 1938, had felt constrained to observe because of the Conformity Act. ${ }^{244}$ This becomes clear when we recall that the power struggle on which the Court focused in this opinion was between the federal government and the states, not between federal district courts and Congress (or the Supreme Court). ${ }^{245}$ Chief Justice Warren (like Judge Wisdom before him) ${ }^{246}$ wrote to vindicate federal power over procedure in federal courts, regardless of whether that power was premised on nationally applicable rules endorsed by Congress or on a district court's need to find effective means to run its local shop. The Hanna court knew that the Federal Rules of Civil Procedure did not satisfy all of the district courts' needs for procedural prescriptions and that federal judges occasionally had to fill gaps by resorting to their inherent power. Chief Justice Warren wanted his opinion to discourage Erie-based challenges, not only to the Federal Rules of Civil Procedure, but also to the less imposing procedural pronouncements the district courts had to base on their "inherent power." Viewed in this light, the passage quoted above represents a firm declaration by the Hanna majority that federal trial courts retain inherent power in procedural matters, power that exists "completely aside from the powers Congress expressly conferred in the Rules." 247

Thus it seems safe to proceed to our second question: is this inherent power a sufficient premise for appointing masters to assist with pretrial discovery matters? Irving $\mathbf{R}$. Kaufman, now Chief Judge of the United States Court of Appeals for the Second Circuit, answered this question with an unequivocal yes in his article in the Columbia Law Review in 1958. ${ }^{248} \mathrm{Judge}$ Kaufman did not attempt to support this view by conducting an independent analysis of the history or scope of the concept of inherent judicial power. Instead, he relied completely on the authority of three cases: $E x$ parte Peterson $^{249}$ and two then relatively recent opinions from the United States Court of Appeals for the Eighth Circuit, Schwimmer v. United

244. See Comments by Edgar B. Tolamn in Hammond, supra note 189, at 129-30, and accompanying quotation from Chief Justice Charles Evans Hughes.

Under the Conformity Act, originally enacted in 1872 , subsequently recodified as former 28 U.S.C. § 724 (1928), supra note 70, the "Modes of proceeding" in federal district courts in actions at law were to "conform, as near as may be, to the . . . modes of proceeding" in the state courts in the place where the federal court sat. Efforts to apply and comply with this statute generated considerable confusion and discontent. See Dobie, supra note 51, at 584-88.

245. Hanna v. Plumer, 380 U.S. at $473-74$.

246. Lumbermen's Mut. Casualty Co. v. Wright, 322 F.2d 759, 764-65 (5th Cir. 1963).

247. Hanna v. Plumer, 380 U.S. at 473.

248. Kaufman, supra note 10, at $462-63,465$ (at the time Kaufman articulated these views he was a United States district judge for the Southern District of New York).

249. 253 U.S. $300(1920)$. 


\section{States $^{250}$ and First Iowa Hydro Electric Cooperative v. Iowa-Illinois Gas \& Electric Co. ${ }^{251}$}

Schwimmer and First Iowa are the only two opinions I have been able to find in which federal courts have maintained that their "inherent power" is a sufficient basis for assigning discovery-related tasks to special masters. ${ }^{252}$ Neither of these opinions, however, included an independent analysis of the scope of inherent power. Instead, both opinions relied on the doctrine articulated in Ex parte Peterson. Thus, Peterson emerges as the primary source from which modern courts have extrapolated the view that federal trial judges have inherent power to appoint special masters to serve during the discovery stage. Is this extrapolation justified? Since neither Schwimmer nor First Iowa attempted to demonstrate how the reasoning in Peterson might support use of masters in the pretrial context, we must undertake that task ourselves.

At the outset I should emphasize that there are parallels between the tasks Judge Hand assigned to the auditor in Peterson and some of the functions masters have served in connection with modern discovery practice. For example, Hand asked the auditor to "make a preliminary investigation as to the facts" and to examine the relevant "books, vouchers and other papers." 293 To complete this assignment, the auditor presumably had to become involved in the process through which the parties identified sources of, and then produced, the relevant data. This process, which for the most part took place at the trial stage in actions at law in the federal system at that time, ${ }^{254}$ was in many respects a functional equivalent of modern discovery.

Hand also asked the auditor to use the evidence he gathered, as well as the exchanges between the parties that would occur during the preliminary hearings, as a basis for separating "items in dispute from those as to which there was no real dispute and, also, to set forth the detailed facts on which

250. 232 F.2d 855 (8th Cir. 1956).

251. 245 F.2d 613 (8th Cir.), cert. denied, 355 U.S. 871 (1957).

252. I know of two published post-1938 cases in which federal courts have relied on inherent power to refer nondiscovery tasks. In Jordan v. Wolke, 75 F.R.D. 696 (E.D. Wis. 1977), the court asked the master to conduct an investigation and then make recommendations about how to shape a temporary injunction that would expand the visitation opportunities for pretrial detainees. The court's entire discussion of its authority to order such a reference consisted of the following sentence: "This appointment is made pursuant to the court's general equity powers and not under Rule 53, Federal Rules of Civil Procedure." Id. at 701.

In Connecticut Importing Co. v. Frankfort Distilleries, 42 F. Supp. 225 (D. Conn. 1940), Judge Hincks decided to appoint a master, before trial, to prepare a report (for ultimate submission to the jury) about the extent of damages caused by alleged Sherman Act violations. The judge believed this task would require analysis of complex accounting data and thus would present "peculiar difficulty for a jury." Id. at 226. The court ordered the master to follow the procedures Rule 53 described for gathering data, holding hearings, and preparing a report. But when Judge Hincks discussed the source of his authority to order such a reference he insisted that his power existed independent of Rule 53. Citing $E x$ parte Peterson and Veneri v. Draper, Judge Hincks declared (without further elaboration): "The power of the court so to proceed is beyond question. It exists independent of the rule. . . Rule 53 serves but to outline the procedure to be followed when the power is exercised." Id. at 227.

253. Id. at 304, 306-7.

254. See Dobie, supra note 53, at 623-32. 
the specific claims made were rested."'25s These also are functions largely performed in modern practice through the machinery of discovery. Moreover, federal judges recently have asked special masters to play central roles in procedures designed to do just what the auditor was to do in Peterson-to supervise systematic exchanges of contentions and evidence in order to produce stipulations and organize material for presentation at trial. ${ }^{256}$

Independent of the overlap between modern discovery and the tasks Hand assigned the auditor, the reasoning through which the Supreme Court upheld Judge Hand's use of the auditor in Peterson strongly suggests that federal judges today have inherent power to delegate discovery duties to masters. The Supreme Court had never evaluated (in an action at law) the kind of compulsory reference that was under review in Peterson. ${ }^{257}$ As a result, Brandeis was forced to resolve the question before him by articulating basic principles about the reach of inherent judicial power: was it broad enough to support this kind of appointment? To answer this question he used two closely related criteria to measure the scope of the power. The first was utility. One reason Brandeis offered for concluding that Hand's order fell within his inherent power was that other courts (e.g., federal equity courts) had found that comparable kinds of references were useful tools for improving the adjudicatory process in complex cases. ${ }^{258}$ The second and more important criterion Brandeis used to measure the reach of inherent power was necessity. He rather freely used words like "essential,"2ss "required," 260 and "necessary" 261 in connection with the master's services, and suggested that neither Hand nor the jury would be able to perform their duties "without the aid to be rendered through the preliminary hearing and report." "262

Words like "required" and "necessary," if taken literally, would severely limit the reach of the judiciary's inherent power. The context in which Brandeis used these words, however, indicates that he did not intend them to be taken literally or to be used to shrivel the concept of inherent power into meaninglessness. There is no reason to believe that the services of an auditor were literally "necessary" to do justice in Peterson. While many commercial transactions had to be analyzed and a great deal of evidence digested, ${ }^{263}$ there is no indication that these tasks could only be performed by a sophisticated specialist. The core issues were conceptually simple: how much coal was delivered in specific shipments and how much of the recipient's obligation remained unpaid. And even by 1920 standards the amount

255. Ex parte Peterson, 253 U.S. at 304, 306-7.

256. Brazil, Hazard, \& Rice, supra note 4, at 315-18.

257. Ex parte Peterson, 253 U.S. at 309, 312.

258. Id. at 312-13.

259. Id. at 314.

260. Id. at 312 .

261. Id. at 306 (describing Judge Hand's justification for the appointment).

262. Id. at 313 .

263. Id. at 306. 
of money in dispute was not huge: plaintiff claimed a balance due of slightly more than $\$ 21,000$, while defendant counterclaimed for just under $\$ 10,000 .{ }^{264}$ Moreover, in defending the appointment of the auditor, Brandeis did not contend that the lawsuit turned on matters beyond the intellectual capacity of the judge or jury. Indeed, he insisted that the jury would retain ultimate responsibility for evaluating the probative force of the evidence and for deciding the contested factual issues. ${ }^{265}$ And under the scenario Brandeis approved, after the auditor completed his work, the parties were to be given opportunities to contest his tentative findings by submitting evidence and argument directly to the jury. ${ }^{266}$

Instead of focusing on intellectual limitations of judge or jury, Brandeis' justification for the appointment of the auditor emphasized how much the use of this "instrument for the administration of justice" ${ }^{267}$ would improve the efficiency of the adjudicatory process. For example, when describing how equity courts had used special masters he declared:

\footnotetext{
Whether such aid shall be sought is ordinarily within the discretion of the trial judge; but this court has indicated that where accounts are complex and intricate, or the documents and other evidence voluminous, or where extensive computations are to be made, it is the better practice to refer the matter to a special master or commissioner than for the judge to undertake to perform the task himself. ${ }^{268}$
}

And when he discussed the role the auditor would play in Peterson, Brandeis did not ascribe importance to the tentative opinions the auditor would express about the liability questions. Instead, he emphasized how much the auditor's work would streamline the case and expedite the trial. He stressed, for example, the contribution the auditor would make by eliminating matters not in dispute and by organizing the evidence relevant to deciding the contested issues. ${ }^{269} \mathrm{He}$ also argued that because the auditor's report could be used "as prima facie evidence both of the evidentiary facts and of the conclusions of fact therein set forth," submitting that report to the jury "would tend to dispense with the introduction at trial before the jury of evidence on any matter not actually in dispute. The appointment of the auditor would thus serve to shorten the jury trial, by reducing both the number of facts to be established by evidence and the number of questions in controversy. A more intelligent consideration of the issues submitted to the jury for final determination would result." 270

Thus, a careful reading of Peterson reveals that the court decided that the appointment of the auditor fell within the trial judge's inherent power not because it would have been literally impossible to do justice without the au- 
ditor's service, but because his efforts would conserve valuable judicial resources, improve the efficiency of the dispute resolution process, and rationalize the jury's work by helping it focus directly on the contested issues and relevant evidence. In other words, to understand how Brandeis used words like "necessary" and "essential" it is imperative to ask: necessary or essential to what? Brandeis probably would not have insisted that the auditor's work was "essential" to an accurate resolution of the dispute; eventually, with enough time and work, the judge and jury could have sorted things out. Rather, Brandeis concluded that the auditor's contribution was "necessary" to maximize the efficiency of arriving at an accurate resolution. Thus what the auditor.was "required" for was to make the litigation process as expeditious and orderly as possible. And, since it is not possible to determine in advance which procedures or forms of assistance are literally "necessary" to maximize efficiency, Brandeis' approach converts the meaning of terms like "necessary" and "essential" into "very useful." 271

Following Brandeis' approach in Peterson, a federal judge would have inherent power to refer discovery matters whenever he or she reasonably believes that the reference would contribute substantially to the expedition and orderliness of case preparation and conserve judicial resources for which there are more pressing needs. A court trying to cope with the pretrial demands of complex civil litigation could reasonably hold such views in many situations. Since I have described many of those situations elsewhere, ${ }^{272} \mathrm{I}$ will simply suggest here that there is no litmus paper test for identifying the circumstances in which pretrial references would be justified, ${ }^{273}$ and that appellate courts probably will give trial judges considerable discretion in making this judgment.

\section{CONCLUSION}

To conclude that the district courts are not powerless to delegate discovery tasks to masters is not to conclude that there is no need for an addition

271. Other courts reportediy have endorsed a similar approach to measuring the scope of inherent power. Thus, according to commentators who have studied many pronouncements by state courts in this general subject area, the " 'inherent power of the judiciary' is generally said to allow a constitutional court to do whatever is reasonably necessary to preserve and guarantee the efficient and orderly administration of justice." Comment, Inherent Power and Administrative Court Reform, 58 Marq. L. Rev. 133, 136 (1975).

272. See the text accompanying notes 20-81 in Brazil, supra.

273. The Handbook of Recommended Procedures for the Trial of Protracted Cases (Report of the Judicial Conference Study Group on Procedure in Protracted Litigation), 25 F.R.D. 351, 391 (1960) notes that it "is difficult to define with any degree of precision the exceptional circumstances under which a pre-trial master's services will be justified." The Handbook then identifies "certain factors" that may serve "as indicia of such a case." The factors discussed are: (1) "inordinate size and complexity" of a case, such that "it would be impossible for any judge to devote the time necessary for adequate supervision of discovery"; (2) "extensive discovery or parts of it will be conducted in places distant from the court"; (3) "the existence of undue animosity among the attorneys or parties." Id. at 391-92. The authors of the Handbook add that "[n]ot every case calls for the full range of services" offered by a special master appointed to supervise the entire discovery process; they cited as an example of an appropriate (but more limited) reference a case where the master's sole function was to resolve disputes about assertions of privilege made with respect to a number of documents. Id. at 391 . 
to the Federal Rules of Civil Procedure. Since the scope of "inherent power" in this context is not clear, since the cases offer no meaningful guidance to federal judges about when and how to exercise this power in the developmental stages of civil actions, and since misuse of this power could threaten litigants' rights and damage the public's confidence in the adjudicatory system, the Advisory Committee should propose a new rule (or an addition to Rule 16) that explicitly authorizes federal judges to assign pretrial duties to special masters (with or without the consent of the parties) and helps the courts identify the circumstances under which such assignments would be appropriate. The new rule also should provide guidance about how to structure and monitor appointments of masters in the pretrial period. ${ }^{274}$ 


\section{APPENDIX 1}

FEDERAL RULES OF CIVIL PROCEDURE 53

\section{Rule 53. Masters}

\section{(a) Appointment and compensation}

Each district court with the concurrence of a majority of all the judges thereof may appoint one or more standing masters for its district, and the court in which any action is pending may appoint a special master therein. As used in these rules the word "master" includes a referee, an auditor, an examiner, a commissioner, and an assessor. The compensation to be allowed to a master shall be fixed by the court, and shall be charged upon such of the parties or paid out of any fund or subject matter of the action, which is in the custody and control of the court as the court may direct. The master shall not retain his report as security for his compensation; but when the party ordered to pay the compensation allowed by the court does not pay it after notice and within the time prescribed by the court, the master is entitled to a writ of execution against the delinquent party.

\section{(b) Reference}

A reference to a master shall be the exception and not the rule. In actions to be tried by a jury, a reference shall be made only when the issues are complicated; in actions to be tried without a jury, save in matters of account and of difficult computation of damages, a reference shall be made only upon a showing that some exceptional condition requires it.

\section{(c) Powers}

The order of reference to the master may specify or limit his powers and may direct him to report only upon particular issues or to do or perform particular acts or to receive and report evidence only and may fix the time and place for beginning and closing the hearings and for the filing of the master's report. Subject to the specifications and limitations stated in the order, the master has and shall exercise the power to regulate all proceedings in every hearing before him and to do all acts and take all measures necessary or proper for the efficient performance of his duties under the order. He may require the production before him or evidence upon all matters embraced in the reference, including the production of all books, papers, vouchers, documents, and writings applicable thereto. He may rule upon the admissibility of evidence unless otherwise directed by the order of reference and has the authority to put witnesses on oath and may himself examine them and may call the parties to the action and examine them upon oath. When a party so requests, the master shall make a record of the evidence offered and excluded in the same manner and subject to the same limitations as provided in Rule 43(c) for a court sitting without a jury.

\section{(d) Proceeding}

(1) Meetings. When a reference is made, the clerk shall forthwith furnish the master with a copy of the order of reference. Upon receipt thereof unless the order of reference otherwise provides, the master shall forthwith set a time and place for the first meeting of the parties or their attorneys to be held within 20 days after the date of the order of reference and shall notify the parties or their attorneys. It is the duty of the master to proceed with all reasonable diligence. Either party, on notice to the parties and master, may apply to the court for an order requiring the master to speed the proceedings and to make his report. If a party fails to appear at the time and place appointed, the master may proceed ex parte or, in his discretion, adjourn the proceedings to a future day, giving notice to the absent party of the adjournment.

(2) Witnesses. The parties may procure the attendance of witnesses before the master by the issuance and service of subpoenas as provided in Rule 45. If without adequate excuse a witness fails to appear or give evidence, he may be punished as for a contempt and be subjected to the consequences, penalties, and remedies provided in Rules 37 and 45 . 


\section{Review Section}

Edited by Howard S. Erlanger

\section{REVIEW ESSAYS}

Carrie Menkel-Meadow

Women in Law? A Review of Cynthia Fuchs Epstein's Women in Law

John Hagan

Pride and Punishment: On the Social History of Criminal Sanctions

Douglas W. Maynard

Language in the Court

Dennis O. Lynch

Hundred Months of Solitude: Myth or Reality in Law and Development?

Lawrence Baum

Understanding Courts as Policy Makers

Werner Pfennigstorf \& Spencer L. Kimball

Aspects of Legal Expense Insurance: A Review of Four New

Publications

\section{BOOK REVIEWS}

The Paradox of Drinking-Driving: Gusfield's Culfure of Public Problems

Zimring, The Changing Legal World of Adolescence

Wexler, Menfal Health Law: Major Issues 


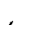

\section{.}

